\title{
Attenuation of Oxidative Stress in HEK 293 Cells by the TCM Constituents Schisanhenol, Baicalein, Resveratrol or Crocetin and Two Defined Mixtures
}

\author{
John R. Bend ${ }^{1,2}$, Xue Yan Xia ${ }^{1}$, Daofeng Chen ${ }^{3}$, Abudi Awaysheh ${ }^{1}$, Andrea $\mathrm{Lo}^{1}$, Michael J. Rieder ${ }^{2,4,5}$ and R. Jane Rylett ${ }^{2,5}$ \\ ${ }^{1}$ Department of Pathology and Laboratory Medicine, Schulich School of Medicine \& Dentistry, Siebens-Drake Medical \\ Research Institute, Western University, London ON. ${ }^{2}$ Department of Physiology and Pharmacology, Schulich School of \\ Medicine \& Dentistry, Western University. ${ }^{3}$ Department of Pharmacognosy, School of Pharmacy, Fudan University, \\ Shanghai, China. ${ }^{4}$ Department of Paediatrics, Schulich School of Medicine \& Dentistry, Western University. ${ }^{5}$ Molecular \\ Medicine, Robarts Research Institute, Western University.
}

Received, July 7, 2015; Revised, August 27, 2015; Accepted, October 22, 2015; Published, October 26, 2015.

ABSTRACT - PURPOSE: Our working hypothesis is that single bioactive phytochemicals with antioxidant properties that are important constituents of Traditional Chinese Medicine (TCM) and their defined mixtures have potential as chemoprotective agents for chronic conditions characterized by oxidative and nitrosative stress, including Alzheimer's. Here we evaluate the ability of baicalein, crocetin, trans-resveratrol or schisanhenol and two defined mixtures of these TCM phytochemicals to attenuate the toxicity resulting from exposure to cell permeant $t$-butyl hydroperoxide (tBPH) in wild-type and bioengineered (to express choline acetyltransferase) HEK 293 cells. METHODS: Endpoints of tBHP-initiated oxidative and nitrosative stress in both types of HEK 293 cells and its attenuation by TCM constituents and mixtures included cytotoxicity (LDH release); depletion of intracellular glutathione (GSH); formation of S-glutathionylated proteins; oxidative changes to the disulfide proteome; and real-time changes in intracellular redox status. RESULTS: At low $\mu$ M concentrations, each of the TCM constituents and mixtures effectively attenuated intracellular toxicity due to exposure of HEK 293 cells to 50 or $250 \mu \mathrm{M}$ tBHP for $30 \mathrm{~min}$ to $3 \mathrm{~h}$. Confocal microscopy of HEK 293 cells transfected with mutated green fluorescent protein (roGFP2) showed effective attenuation of tBHP oxidation by baicalein in real time. Three redox-regulated proteins prominent in the disulfide proteome of HEK 293 cells were identified by MALDI-TOF mass spectrometry. CONCLUSIONS: We conclude that single TCM chemicals and their simple mixtures have potential for use in adjunct chemoprotective therapy. Advantages of mixtures compared to single TCM constituents include the ability to combine compounds with varying molecular mechanisms of cytoprotection for enhanced biological activity; and to combine chemicals with complementary pharmacokinetic properties to increase half-life and prolong activity in vivo.

This article is open to POST-PUBLICATION REVIEW. Registered readers (see "For Readers") may comment by clicking on ABSTRACT on the issue's contents page.

\section{INTRODUCTION}

Reactive oxygen species (ROS)(1) and reactive nitrogen species (RNS)(2) are formed as by-products during normal cellular metabolism. In healthy mammalian cells, physiological concentrations of ROS and RNS are detoxified by enzymatic antioxidants including catalase, enzymes of the glutathione (GSH) oxidation-reduction cycle [GSH reductase and GSH peroxidase], the peroxiredoxins (prxs), and superoxide dismutase (SOD) in addition to the common non-enzymatic antioxidants GSH, Vitamins $\mathrm{C}$ and $\mathrm{E}, \beta$-carotene and uric acid (3). Increased, pathological concentrations of ROS and
RNS overwhelm these normal detoxication pathways and contribute to several chronic diseases, including AIDS, atherosclerosis, cancer, diabetes, and neurodegenerative disorders such as Alzheimer's and Parkinson's disease (4-7). Thus, decreased formation and/or increased detoxication of ROS and RNS can attenuate the severity of chronic disease caused or promoted by toxic free radicals.

\footnotetext{
Corresponding Author: Professor Jack Bend, Department of Pathology and Laboratory Medicine, Schulich School of Medicine \& Dentistry, Siebens-Drake Medical Research Institute, Western University, 1400 Western Road, London ON, Canada; Email: jack.bend@schulich.uwo.ca
} 
Their antioxidant activity is one explanation for the chemoprotective and neuroprotective effects of several foods and dietary supplements $(8,9)$, and for some of the therapeutic effects of plant-based TCM (10).

The association between the administration of potent antioxidants and the attenuation of free radical-induced disease $(3,9,10)$ influenced our choice of specific TCM constituents for evaluation both in a recent study of sulfamethoxazole Nhydroxylamine- (SMX-NHOH-) mediated cytotoxicity in Jurkat E6.1 cells (11) and in the present study. Here, we evaluated the chemoprotectant effects of these four major TCM constituents (baicalein (BE), crocetin (Cro), transresveratrol (Res) and schisanhenol (Sal) and two defined mixtures against the well characterized, cellpermeant oxidative and nitrosative stressor, tertiarybutyl hydroperoxide (tBHP) $(12,13)$ in wild-type (WT) transformed human renal epithelial cells (HEK 293) cells and HEK 293 cells bioengineered to express the cholinergic neuron-specific enzyme choline acetyltransferase (ChAT, EC 2.3.1.6) $(14,15)$ (ChAT-HEK 293 cells). Recognizing that TCMs also have cytoprotective effects due to modulation of cell signalling pathways (16-19), we sought to optimize the opportunity for complementary biological activity in our defined mixtures by selecting four TCM antioxidants of varying structure and chemical class (Figure 1) with known and diverse mechanisms of antioxidant and cytoprotective activity.

Baicalein $\quad(\mathrm{BE}) \quad[5,6,7$-trihydroxy-2phenylchromen-4-one] (Figure 1B) $(16,20-24)$ is the flavonoid found at highest concentration in the root of Scutellaria baicalensis, a common component of TCM prescriptions. The di-ortho phenolic hydroxyl group on benzeneoid ring-A of BE is associated with efficient divalent metal ion chelation and free radical scavenging properties, accounting for its antioxidant properties $(20,23,24)$. In addition, repeated treatment with $\mathrm{BE}$ reduces the production of ROS by the upregulation of peroxiredoxin-6 (prx-6) (24), which decreases intracellular $\mathrm{H}_{2} \mathrm{O}_{2}$ content. $\mathrm{BE}$ also inhibits the production of iNOS after stimulation with LPS, resulting in the attenuated release of the proinflammatory cytokines IL- $1 \beta$, IL- 6 , and TNF- $\alpha$ (24). BE decreases lipid peroxidation and protects against DNA damage by forming stable semiquinone radicals, and blocks mitochondrial depolarization (24).
Crocetin (Cro) [(2E,4E,6E,8E,10E,12E,14E)2,6,11,15-tetramethylhexadeca-2,4,6,8,10,12,14heptaenedioic acid] (Figure 1D) is a carotenoid that provides the colour to Saffron extracts and is its major active ingredient (25). The presence of seven trans-conjugated 1,3-double bonds accounts for its antioxidant properties (25). Of significance, Cro is a much more potent intracellular antioxidant than when tested in cell free systems (26), acting by reducing superoxide anion radical (O2 •-) production. In cells, Cro is also able to capture the sulfite radical anion, $\mathrm{SO}_{3^{-}}$(26). Repeated administration of Cro also induces the activity of the important antioxidant enzymes, GSH S-transferase and GSH peroxidase (25).

Trans-resveratrol (Res) [5-[(E)-2-(4hydroxyphenyl)ethenyl]benzene-1,3-diol] (Figure 1C) a phytoalexin that is more stable than its cisisomer, primarily owes its antioxidant activity to its three phenolic groups, two ortho hydroxyls in one benzeneoid ring and one para group in the second ring (27). Mechanistic studies showed the parahydroxyl group scavenges free radicals more effectively than its ortho-hydroxyl groups (28). Res directly scavenges superoxide anion and hydroxyl radicals (28), and reduces their formation by inhibiting xanthine oxidase activity (29).

Schisanhenol (Sal) [5,6,7,8-tetrahydro2,3,10,11,12-pentamethoxy-6,7-dimethyl-

dibenzo(a,c)cycloocten-1-ol] (Figure 1A) is a dibenzocyclooctene lignin isolated from Schisandra rubriflora Rhed, an herb common in TCM prescriptions (30). Studies with this purified TCM are uncommon because of its restricted availability. Sal effectively targets mitochondria due to its enhanced lipophilicity (5 methoxylated phenolic groups) compared to compounds with only free antioxidant polyphenols (30), an important reason for our interest in this compound. Prior to cytochrome P-450-dependent O-demethylation, its antioxidant activity is due to a single phenolic hydroxyl group. Metabolic O-demethylation liberates 5 additional antioxidant phenolic hydroxyls in this molecule. Sal inhibits lipid peroxidation (31), swelling, and reduction of mitochondrial membrane fluidity due to ROS-mediated damage (32). Sal is a strong scavenger of superoxide anion $\left(\mathrm{O}_{2} \bullet-\right)$, alkyl $(\mathrm{R} \bullet-)$, alkoxy $(\mathrm{RO} \bullet-)$, and carboxy ( $\mathrm{ROO} \bullet-)$ radicals (33). Repeated treatment of rats induces antioxidant superoxide dismutase and catalase activities in liver cytosol (34). To date, there have been no detailed 
studies of the effects of Sal on cell signalling networks.

In a recent study (11), we showed these individual TCM constituents and two defined mixtures effectively attenuated the oxidative/nitrosative stress-mediated cytotoxicity of sulfamethoxazole N-hydroxylamine (SMX-NHOH), a toxic reactive metabolite of sulfamethoxazole, in Jurkat E6.1 cells. More specifically, pre-treatment of cells with $5 \mu \mathrm{M}$ MIX or MIX-S for 30 min prior to incubation with $400 \mu \mathrm{M}$ SMX-NHOH for $2 \mathrm{~h}$ decreased cytotoxicity by $93.4 \pm 0.8 \%$ (mean \pm SEM, $\mathrm{N}=3$ ) and $93.1 \pm 0.4 \%$, respectively. By comparison, the least effective TCM, $5 \mu \mathrm{M} \mathrm{BE}$, inhibited cytotoxicity by $57.5 \pm 1.91 \%(\mathrm{P} \leq 0.05$ vs MIX (equimolar amounts of BE, Cro, Res, Sal) or MIX-S (equimolar BE, Cro, Res) and the most effective, Sal attenuated SMX-NHOH toxicity by $82.4 \pm 1.3 \%$ ( $\mathrm{P} \leq 0.05 \mathrm{vs} \mathrm{BE})$. These data encouraged us to investigate these TCM mixtures in further detail.

Low and moderate intracellular oxidative stress can cause reversible post-translational modification of proteins, compromising enzyme activity by altering protein structure and conformation. SGlutathionylated proteins (PSSG; proteinglutathione mixed disulfides) are formed by both ROS and RNS at reactive (ionized) cysteine thiol residues upon reaction with GSH. As a cell recovers from oxidative/nitrosative stress these disulfides are reduced to $\mathrm{GSH}$ and $\mathrm{PSH}$, restoring homeostasis $(7,35,36)$. The conversion of reactive (increased electrophilicity) cysteine thiols in proteins to their
GSSP derivatives, and to protein-protein disulfides (PSSP) when GSH is depleted, occurs selectively in response to ROS or the RNS, NO (as NO-GSH). These changes, including the protein disulfides formed, are the disulfide proteome $(7,35,36)$.

Consequently, we compared the Sglutathionylation of intracellular proteins in WTHEK 293 cells and ChAT-HEK 293 cells treated with tBHP, the latter to determine if ChAT is a redox regulated protein. This is of importance because ChAT is a critical enzyme in cholinergic neurons whose activity decreases early in the development of Alzheimer's $(14,15)$. In addition, we analyzed tBHPmediated changes to the disulfide proteome of HEK 293 cells by reductive two-dimensional (R2D) SDSPAGE and the attenuation of these changes by pretreatment with Sal, BE, Cro or Res, (Figure 1) alone or as two equimolar TCM mixtures. In supplementary experiments, attenuation of tBHP initiated cytotoxicity (studied by LDH release) and GSH depletion were studied with some but not all TCM treatments. Changes in intracellular redox potential in HEK 293 cells transfected with mutated green fluorescence protein (roGFP2) were followed in real time by confocal microscopy immediately after exposure to tBHP. The ability of BE, a well investigated TCM antioxidant, to attenuate these effects was also evaluated.

Finally, we identified three of the important redox regulated proteins in the disulfide proteome of HEK 293 cells by MALDI-TOF MS analysis of ingel tryptic digests of proteins separated by R2D SDS PAGE.

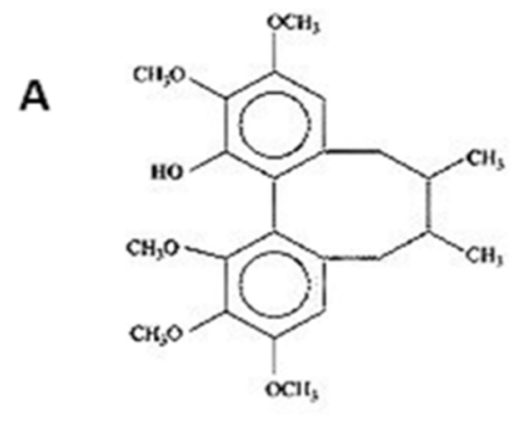

C

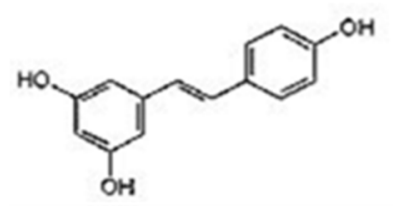

B<smiles>O=c1cc(-c2ccccc2)oc2cc(O)c(O)c(O)c12</smiles>

D

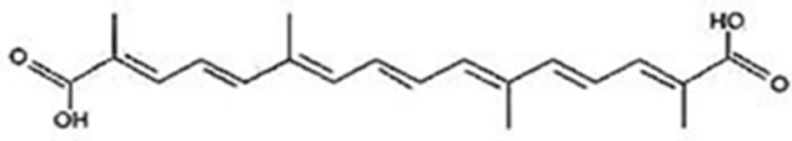

Figure 1: Chemical structures of the phytochemicals studied. A, Schisanhenol (Sal); B, Baicalein (BE); C, trans-Resveratrol (Res); and D, Crocetin (Cro) (From PubChem Public Database, http://pubchem.ncbi.nlm.nih.gov) 


\section{MATERIALS AND METHODS}

\section{Chemicals}

1-Chloro-2,4-dinitrobenzene (DNCB), dithiothreitol (DTT), ethyl glutathione (EtGSH), GSH, GSSG, GSH S-transferases, iodoacetamide (IACD), tBHP, Cro, Res and N-methylphenazonium methyl sulfate (PMS) were purchased from Sigma-Aldrich (Oakville, ON, Canada). The anti-GSH monoclonal antibody was obtained from Virogen (Watertown, MA, USA), the anti- $\beta$-actin monoclonal from Sigma, and the anti-ChAT CTab polyclonal antibody was prepared by Genemed Synthesis (San Antonio, TX, USA) (14). All other chemicals were purchased from BDH (Toronto, ON, Canada), EMD (San Diego, CA, USA) or Sigma-Aldrich and were the highest purity commercially available.

\section{Cell Culture and Treatments with TCM Constituents and Mixtures}

WT-HEK 293 (ATCC $^{\circledR}$ CRL-1573 ${ }^{\text {TM }}$ ) cells were obtained from ATCC (Manassas, VA, USA) and maintained in a humidified atmosphere at $37^{\circ} \mathrm{C}$ and $5 \% \mathrm{CO}_{2}$ in Eagle's Minimum Essential Medium (Gibco, Carlsbad, CA) supplemented with $10 \%$ fetal bovine serum (FBS), $26 \mathrm{mM} \mathrm{NaHCO}_{3}$ and $10 \mu \mathrm{g} / \mathrm{mL}$ gentamycin sulfate. WT- or ChAT-HEK 293 cells (preparation described in 14) were plated $24 \mathrm{~h}$ prior to treatment and then incubated with various concentrations $(10-100 \mu \mathrm{M})$ of Sal, BE, Res or Cro individually, or with a mixture of the four antioxidants at equimolar concentrations (MIX), or an equimolar mixture of BE, Res and Cro without Sal (MIX-S) for $30 \mathrm{~min}$. Following this incubation step, cells were exposed to either 50 or $250 \mu \mathrm{M}$ tBHP for $30 \mathrm{~min}$ to $3 \mathrm{~h}$. The effects of MIX-S were tested to determine whether Sal was a significant contributor to the protective effects of the complete mixture (MIX). Solutions of antioxidants were freshly prepared in dimethyl sulfoxide (DMSO), and cells were treated with TCM in no more than $0.2 \%$ DMSO. Protein concentrations were determined using the Lowry procedure (37).

\section{Lactate Dehydrogenase (LDH) Activity}

Cytotoxicity was examined by measuring release of intracellular LDH activity with a colorimetric assay described in detail elsewhere $(11,38)$. Briefly, WTor ChAT-HEK 293 cells were plated at $8 \times 10^{4}$ cells in a 96-well culture plate for $24 \mathrm{~h}$ before treatment. Culture media was replaced with phosphate buffered saline (PBS) before antioxidant treatment $(0-100 \mu \mathrm{M}$ for $30 \mathrm{~min}$ ). Cells were then treated for $3 \mathrm{~h}$ with 0 $500 \mu \mathrm{M}$ tBHP or the detergent $1 \%$ Triton X-100 (which released all LDH) for cytotoxicity. After incubation, cell supernatant $(100 \mu \mathrm{L})$ was removed and incubated with LDH Reaction Mixture $(100 \mu \mathrm{L})$. Released LDH activity was analyzed by measuring absorbance at $490 \mathrm{~nm}$ (Safire F129013, Tecan, Austria) and correction for LDH release in solvent controls.

\section{Determination of Intracellular Glutathione (GSH) Concentration}

Cells were plated at $8 \times 10^{5}$ cells/well in 6 -well plates and cultured for $24 \mathrm{~h}$. Cells were incubated with TCM constituents $(10-50 \mu \mathrm{M}$ for $30 \mathrm{~min})$, then treated with $0-500 \mu \mathrm{M}$ tBHP for $30 \mathrm{~min}$ and centrifuged for $5 \mathrm{~min}$ at $500 \mathrm{xg}$. Cell pellets were resuspended in $250 \mu \mathrm{L}$ lysis buffer $(10 \mathrm{mM}$ Tris, 130 $\mathrm{mM} \mathrm{NaCl}, 10 \mathrm{mM}$ NaF, $10 \mathrm{mM} \mathrm{NaH}{ }_{2} \mathrm{PO}_{4}, 10 \mathrm{mM}$ $\mathrm{Na}_{4} \mathrm{P}_{2} \mathrm{O}_{7}, 2 \mathrm{mM}$ EDTA) and frozen in liquid nitrogen. Cell lysates were thawed at room temperature and aliquots taken for protein analysis (Bradford Bio-Rad Assay Kit). Remaining lysate was centrifuged for $2 \mathrm{~min}$ at $14,000 \mathrm{xg}$ and supernatant collected for GSH analysis by the GSH S-transferase enzymatic method (39). Supernatant $(50 \mu \mathrm{L})$ and $0.1 \mathrm{M}$ potassium phosphate buffer (140 $\mu \mathrm{L}, \mathrm{pH} 7.6)$ were added to a 96 -well plate to which were added $40 \mathrm{mM}$ ethanolic DNCB $(5 \mu \mathrm{l})$ and GSH S-transferase $(0.2 \mathrm{U})$. Reaction mixtures were incubated in the dark at room temperature for $20 \mathrm{~min}$ and the S-2,4-dinitrophenyl GSH formed quantitated by absorbance at $340 \mathrm{~nm}$ (39). To quantify GSSG, aliquots of the same incubation mixtures used for GSH analysis were treated with NADPH and GSH reductase to convert all GSSG to GSH; then Total GSH content equalled the amount of S-2,4dinitrophenyl GSH present after reduction of GSSG. Sample GSSG content was calculated as the difference between Total GSH (GSH + GSSG) and Sample GSH content.

\section{Intracellular Redox Status Determined with Transiently Transfected roGFP2}

Intracellular redox status of HEK 293 cells was measured in real time by confocal laser scanning microscopy (LSM 510 META, Carl Zeiss Advanced 
Imaging Microscopy, Germany) using a novel redox-sensitive mutated green fluorescent protein (roGFP2) $(40,41)$ in which two cysteine residues were introduced near the chromophore site (S147C and Q204C). Under oxidizing conditions, a reversible intramolecular disulfide bond is formed between these two cysteine thiols resulting in increased fluorescence excitability at $405 \mathrm{~nm}$ and decreased excitability at $488 \mathrm{~nm}$ (emission $530 \mathrm{~nm}$ ) so that oxidized and reduced forms of the transfected roGFP can be quantified. For these experiments, either WT- or ChAT-HEK 293 cells were plated at a density of $1 \times 10^{6}$ cells $/ 100 \mathrm{~mm}$ tissue culture dish and cultured for $24 \mathrm{~h}$. Cells were transiently transfected with roGFP2 plasmid DNA at $10 \mu \mathrm{g} /$ dish for $6 \mathrm{~h}$ using ExGen 500 transfection reagent (Fermentas International Inc, Burlington, CA). After $6 \mathrm{~h}$, excess roGFP2 plasmid DNA was removed by changing the culture media, and cells were incubated for a further $24 \mathrm{~h}$. Cells were re-plated at a density of $2 \times 10^{5}$ cells/dish in $35 \mathrm{~mm}$ glass-bottomed confocal culture dishes for $24 \mathrm{~h}$ to allow cells to adhere. For cell treatment, $50 \mu \mathrm{M}$ tBHP or $10 \mu \mathrm{M} \mathrm{BE}+50 \mu \mathrm{M}$ tBHP were added with continuous monitoring of 405 $\mathrm{nm} / 488 \mathrm{~nm}$ excitation fluorescence changes by confocal microscopy. roGFP2 plasmid DNA was obtained as a gift from Professor James Remington via a Material Transfer Agreement between Western University and the University of Oregon.

\section{Analysis of S-Glutathionylated (PSSG) Proteins by One-Dimensional Non-Reducing SDS-PAGE plus Western Immunoblot}

WT- or ChAT-HEK 293 cells were plated at $8 \times 10^{5}$ per well in 6-well plates and cultured for $24 \mathrm{~h}$. Culture media was replaced with PBS before treatment with TCM constituents at $0-100 \mu \mathrm{M}$ for 30 min prior to addition of $0-250 \mu \mathrm{M}$ tBHP for $30 \mathrm{~min}$. Cytosolic fractions containing $75 \mu \mathrm{g}$ protein were obtained (see GSH analysis above) and resolved using $4-12.5 \%$ non-reducing SDS-PAGE gradient gels. Following electrophoresis, proteins were transferred to PVDF membranes (PALL Corp., Ann Arbor, MI), membranes were blocked overnight at $4^{\circ} \mathrm{C}$ using Tris-saline buffer, $\mathrm{pH} 7.4$ with $5 \%$ skim milk powder. Blots were probed with either antiGSH antibody (1:2,000 dilution) or with anti-ChAT antibody (14) $(1: 2,000)$ and anti- $\beta$-actin monoclonal antibody for $1 \mathrm{~h}$. Following washing (Tris-saline buffer containing $0.1 \%$ Tween 20 ), membranes were incubated with horseradish peroxidase-linked anti- mouse or anti-rabbit secondary antibody $(1: 10,000$ dilution) (Amersham Biosciences, Buckinghamshire, England). Detection was performed using ECL Plus ${ }^{\mathrm{TM}}$ Western blotting reagents (Amersham Biosciences).

\section{Redox Two-Dimensional SDS-Polyacrylamide Gel Electrophoresis (R2D SDS-PAGE)}

We recently described this procedure (adapted from Cumming et al (42)) in detail elsewhere (11) so a condensed version appears here. Cells, were treated, lysed and centrifuged for $3 \mathrm{~min}$ at $500 \mathrm{xg}$. Cell pellets were washed with PBS, re-centrifuged, resuspended in ice-cold PBS with $40 \mathrm{mM}$ IACD, centrifuged at $500 \mathrm{xg}$ for $3 \mathrm{~min}$ and resulting pellets resuspended in $60 \mu \mathrm{L}$ lysis buffer and frozen in liquid nitrogen. At the time of analysis, lysates were thawed in a water bath at room temperature and centrifuged for $10 \mathrm{~min}$ at $14,000 \mathrm{xg}$. The supernatant was transferred to a fresh tube and assayed for protein content (37).

An equal volume of Laemmli sample buffer, without reducing agents, was added to solubilized cytosolic extracts. SDS-PAGE gels $(10 \%$ acrylamide, $1.0 \mathrm{~mm}$ thickness) were prepared $(11,42)$, and protein samples $(75$ or $85 \mu \mathrm{g}$ ) subjected to electrophoresis in the first dimension for $5 \mathrm{~h}$ at constant current ( $25 \mathrm{~mA}$ ) using a Bio-Rad Protean II apparatus (11). After electrophoresis, the gel lanes containing the separated proteins were cut and immersed in Laemmli sample buffer containing 100 $\mathrm{mM}$ DTT for $20 \mathrm{~min}$. Following a brief wash with electrophoresis running buffer, the gel slices were immersed again in Laemmli sample buffer containing $100 \mathrm{mM}$ DTT for $10 \mathrm{~min}$. Each gel strip was then applied horizontally to another gel $(10 \%$ acrylamide, $1.5 \mathrm{~mm}$ thickness), and electrophoresis was performed in the second dimension for $14 \mathrm{~h}$ at constant current $(10 \mathrm{~mA} / \mathrm{gel})$. Gels were fixed in $50 \%$ methanol, 5\% acetic acid for $20 \mathrm{~min}$, then silver-stained $(11,43)$.

\section{Mass Spectrometry (MS)}

Protein spots that exhibited reproducible migration following R2D SDS-PAGE were excised (Ettan Spot Picker, General Electric Healthcare, Piscataway, NJ). In-gel digestion with sequence grade trypsin, and lyophilization were carried out with a Mass Prep Automated Digestor (Waters, Milford, MA). Lyophilized peptide samples were dissolved in 10\% acetonitrile and $0.1 \%$ trifluoroacetic acid $(5 \mu 1)$, then 
mixed at a $1: 1$ ratio with $5 \mathrm{mg} / \mathrm{mL} \alpha$-cyano-4hydroxycinnamic acid in $6 \mathrm{mM}$ ammonium phosphate monobasic solution. Sample $(0.75 \mu \mathrm{L})$ was spotted on a sample target in duplicate to acquire matrix-assisted laser desorption/ionization (MALDI) MS spectra using a BiosystemsR 4700 Proteomics Discovery System, a matrix-assisted laser desorption/ionization tandem time-of-flight mass spectrometer with TOF/TOF optics (MALDI-TOF).

\section{Protein Identification}

The MALDI MS spectra were converted into data with 4000 Series Explorer software (Applied Biosystems, Foster City, CA), and processed into a peptide mass fingerprint with Data Explorer software (Applied Biosystems, Foster City, CA). Protein identification using peptide mass fingerprints (PMF) from MALDI MS spectra were obtained using a GPS engine connected to a Mascot server provided by the software manufacturer. PMF were compared to known peptide mass sequences obtained from the NCBI database. Samples with a PMF with a high protein score (typically above $90 \%$ ) were predicted to identify a particular protein.

\section{Statistics}

A one-way analysis of variance (ANOVA) followed by Bonferroni's multiple comparison post-hoc test were used to compare groups. The level of significance was $\mathrm{p} \leq 0.05$. When appropriate, Student's $t$-test was used to determine differences between vehicle control and treatment groups. Statistics were performed using GraphPad Prism Version 4.03 (GraphPad Software, Inc).

\section{RESULTS}

\section{Protective effects of Sal and TCM Mixtures on tBHP-mediated Cytotoxicity}

In these experiments, we compared the effects of Sal with those of our defined TCM mixtures on LDH release from cells as shown in Fig. 2. Treatment of cells for 30 min with Sal alone at either 10 or $20 \mu \mathrm{M}$ did not alter LDH release compared to vehicle control. Moreover, neither MIX nor MIX-S at 10, 20 or $100 \mu \mathrm{M}$ resulted in LDH release from cells; MIX contains Sal at a concentration of $25 \mu \mathrm{M}$. As expected, the treatment of cells with the oxidative stressor tBHP $(250 \mu \mathrm{M}$ for $3 \mathrm{~h})$ significantly increased LDH release $(38 \%)(\mathrm{P} \leq 0.05)$. Importantly, when added for 30 min prior to tBHP treatment, all TCM preparations tested were chemoprotective, significantly reducing LDH release from cells $(\mathrm{P} \leq 0.05)$. There were no significant differences between MIX, MIX-S or Sal for the attenuation of tBHP-mediated LDH release at the concentrations tested. Acute treatment of cells with $100 \mu \mathrm{M} \mathrm{Sal}$ resulted in moderate cytotoxicity $(23 \% \mathrm{LDH}$ release compared to vehicle-treated control cells, $\mathrm{P} \leq 0.05$ ) (data not shown).

Of interest, ChAT-HEK 293 cells treated with vehicle $(0.2 \%$ DMSO) released significantly more LDH than did WT-HEK 293 cells (Fig. 3), suggesting the bioengineered cells may be under greater oxidative stress. Importantly, when ChATHEK 293 cells were treated for $30 \mathrm{~min}$ with either 5 or $10 \mu \mathrm{M} \mathrm{BE}, \mathrm{LDH}$ release was reduced to that from WT-HEK 293 cells treated with either vehicle or BE. Treatment of cells with $250 \mu \mathrm{M}$ tBHP resulted in a significant increase in LDH from both WT-HEK 293 and ChAT-HEK 293 cells $(\mathrm{P} \leq 0.05)$, with the increase being significantly greater in ChAT-HEK 293 cells than WT cells $(23 \%$ compared to $11 \%$, respectively; $\mathrm{P} \leq 0.05)$. This suggests enhanced antioxidant activity in the WT- compared to ChATHEK 293 cells. BE pre-treatment at either $5 \mu \mathrm{M}$ or $10 \mu \mathrm{M}$ attenuated tBHP cytotoxicity in both WT- and ChAT-HEK 293 cells with the effects being similar at the two concentrations.

\section{Intracellular GSH Status and Depletion in WT- and ChAT-HEK 293 Cells}

GSH is the main non-enzymatic antioxidant defense within mammalian cells, therefore the concentration of intracellular GSH was determined in ChAT-HEK 293 cells with or without BE treatment, and with and without exposure to tBHP (Figure 4). A concentration-dependent decrease in intracellular GSH was observed after treatment with 50 or 250 $\mu \mathrm{M}$ t-BHP for $1 \mathrm{~h}(25 \%$ and $50 \% \mathrm{GSH}$ depletion, respectively). The GSH content was higher in cells treated with $50 \mu \mathrm{M}$ tBHP for $1 \mathrm{~h}$ than for $30 \mathrm{~min}$, showing partial recovery from the oxidative stressor by $60 \mathrm{~min}$. At a concentration of $10 \mu \mathrm{M}, \mathrm{BE}$ did not alter cellular GSH content relative to the vehicletreated control cells, nor did it provide protection in cells that were treated with $50 \mu \mathrm{M}$ tBHP for $30 \mathrm{~min}$ (36\% vs $35 \%$ GSH depletion in control vs BE treated cells). 


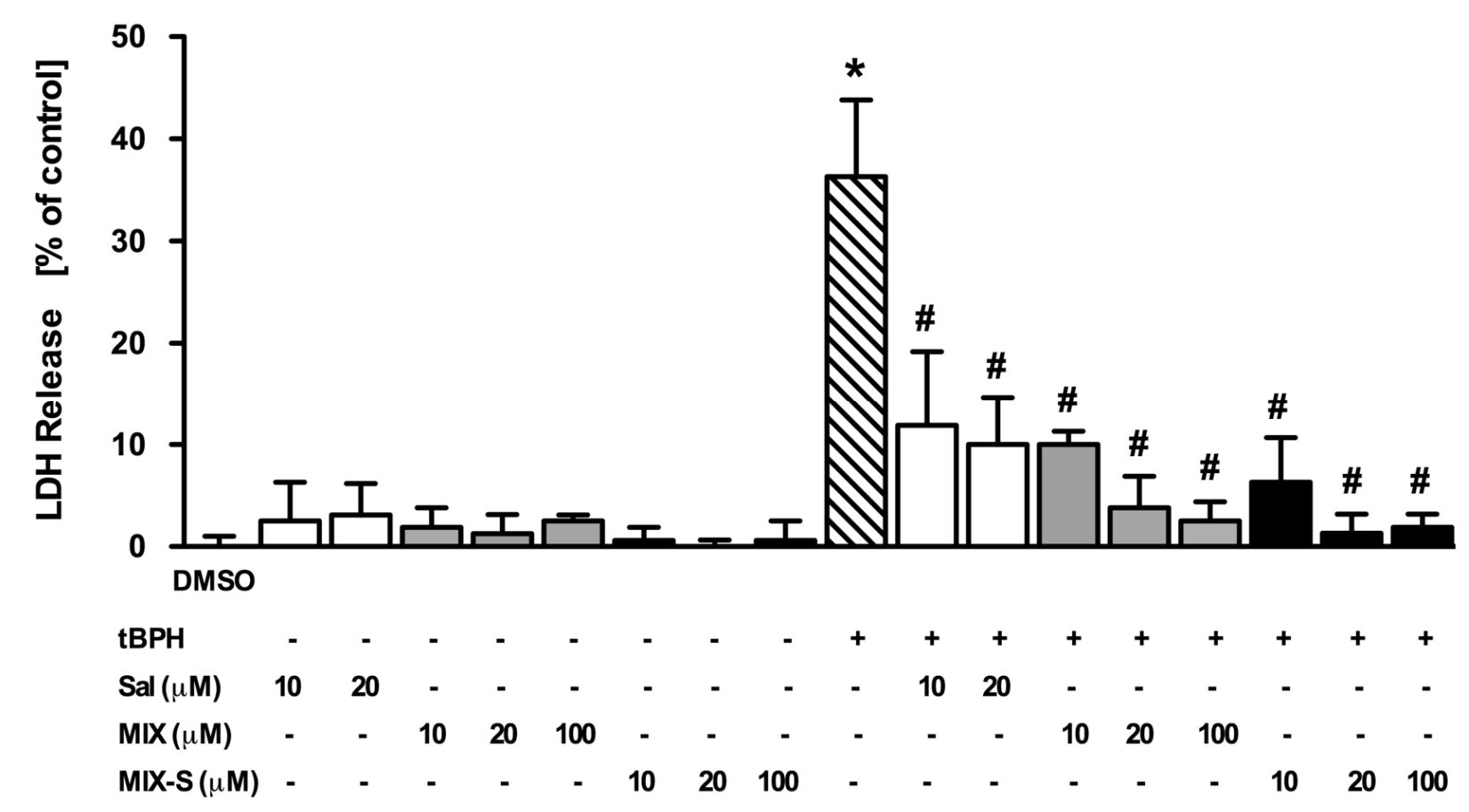

Figure 2: LDH release from WT-HEK 293 cells following pre-treatment with 10, 20 or $100 \mu \mathrm{M}$ TCM for 30 min, with or without subsequent exposure to $250 \mu \mathrm{M}$ tBHP for $3 \mathrm{~h}$. Sal = Schisanhenol; MIX = Equimolar mixture of Sal, Cro, BE, Res; MIX-S = Equimolar mixture of Cro, BE, Res without Sal. Data are shown from 4 separate experiments and expressed as mean \pm SEM. * denotes $\mathrm{P} \leq 0.05$ compared to DMSO-treated control cells; \# denotes $\mathrm{P} \leq 0.05$ compared to $250 \mu \mathrm{M}$ tBHP. Statistical significance between the groups was tested using one-way ANOVA followed by Bonferroni's multiple comparison test and showed no differences $(\mathrm{P}>0.05)$.

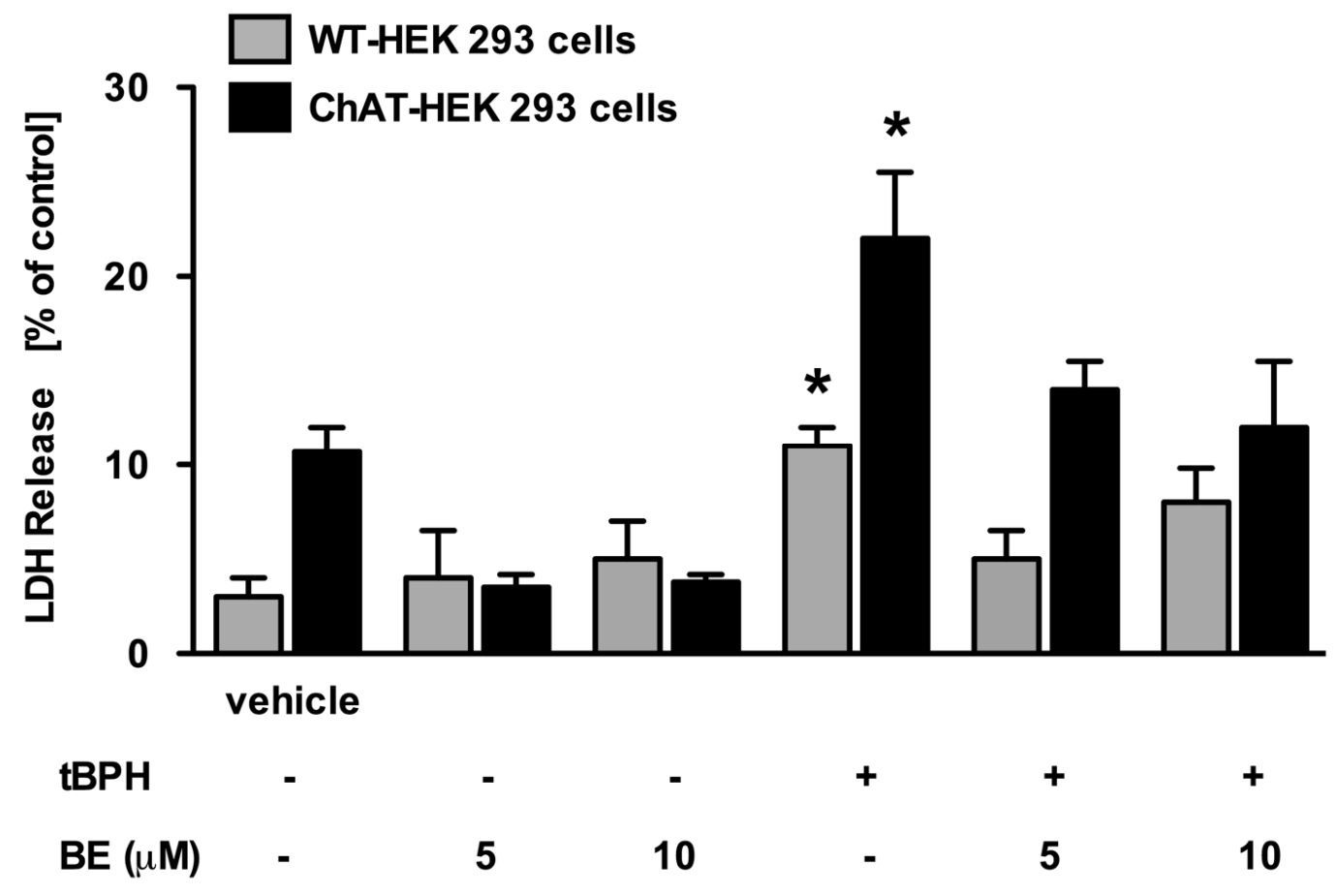

Figure 3: Comparison of LDH release from WT-HEK 293 cells to that from ChAT-HEK 293 cells following pre-treatment with $\mathrm{BE}$ for $30 \mathrm{~min}$, with or without subsequent exposure to $250 \mu \mathrm{M}$ tBHP for $3 \mathrm{~h}$. Data are shown from 4 separate experiments (mean $\pm \mathrm{SEM}$ ). ${ }^{*} \mathrm{P} \leq 0.05$, WT- compared to ChAT-HEK 293 cells (Student's $t$-test). 
On the other hand, BE did provide considerable protection against the oxidative stress associated with exposure to $250 \mu \mathrm{M}$ tBHP for $30 \mathrm{~min}$ (25 vs $50 \%$ GSH depletion, BE vs control).

Consistent with the greater cytotoxicity of tBHP in ChAT-HEK 293 cells (Figure 3), pre-treatment of WT-HEK 293 cells with $10 \mu \mathrm{M}$ BE for $30 \mathrm{~min}$ effectively prevented subsequent tBHP-mediated oxidation and also increased intracellular GSH content (vs controls) more than in the bioengineered cells. For example, GSH depletion (23\%) caused by $50 \mu \mathrm{M}$ tBHP for 30 or $60 \mathrm{~min}$ was completely prevented by $10 \mu \mathrm{M}$ BE pre-treatment $(\mathrm{P} \leq 0.05$; data not shown). However, treatment with $\mathrm{BE} 10 \mu \mathrm{M}$ for $24 \mathrm{~h}$ was less effective than treatment for $30 \mathrm{~min}$ (30\% GSH depletion vs no depletion at $30 \mathrm{~min}$ ). These data emphasize the importance of repeated administration of $\mathrm{BE}$ for effective antioxidant activity due to rapid metabolic conjugation and elimination from mammalian cells in vitro and in vivo.

\section{Detection of Protein-GSH Mixed Disulfides (PSSG) in WT-HEK 293 Cells after Treatment with tBHP}

During oxidative stress, proteins with reactive cysteine thiol residues (PS ${ }^{-}$can be reversibly oxidized to sulfenic acids (PS-OH) which are converted either to $S$-glutathionylated proteins
(PSSG) in the presence of GSH or to protein-protein disulfides (PSSP) in its absence $(7,35,36)$. Analysis of cellular proteins by one-dimensional nonreducing SDS-PAGE coupled with immunochemical detection using anti-GSH antibodies can be used to identify PSSG as immunoreactive bands following electrophoresis of proteins in lysed cells. As shown in Figure 5, cytosol isolated from WT-HEK 293 cells treated with either $250 \mu \mathrm{M}$ or $1 \mathrm{mM}$ tBHP for $30 \mathrm{~min}$ contained many PSSG formed from redox-sensitive proteins compared to either $0.2 \%$ DMSO or BEtreated cells. As verification that PSSG are formed, these bands were absent in aliquots of these samples treated with $100 \mu \mathrm{M}$ DDT which reduces both PSSG and PSSP. Treatment of cells with $10 \mu \mathrm{M} \mathrm{BE}$ for 30 min did not attenuate PSSG formation initiated by tBHP, emphasizing that these GSH-containing disulfides are part of the detoxication process. They are readily reduced to original PSH and GSH as the cell returns to its (normal) redox potential $(35,36)$.

\section{Detection of PSSG, Including ChAT-SSG, and PSSP Containing ChAT Resulting from Oxidative Stress in ChAT-HEK 293 Cells}

Treatment of ChAT-HEK 293 cells with $250 \mu \mathrm{M}$ tBHP for $30 \mathrm{~min}$ also resulted in the formation of many PSSG, as shown in the non-reduced gel stained with anti-GSH antibody (Figure 6). Of particular interest is the strong, single protein band with an

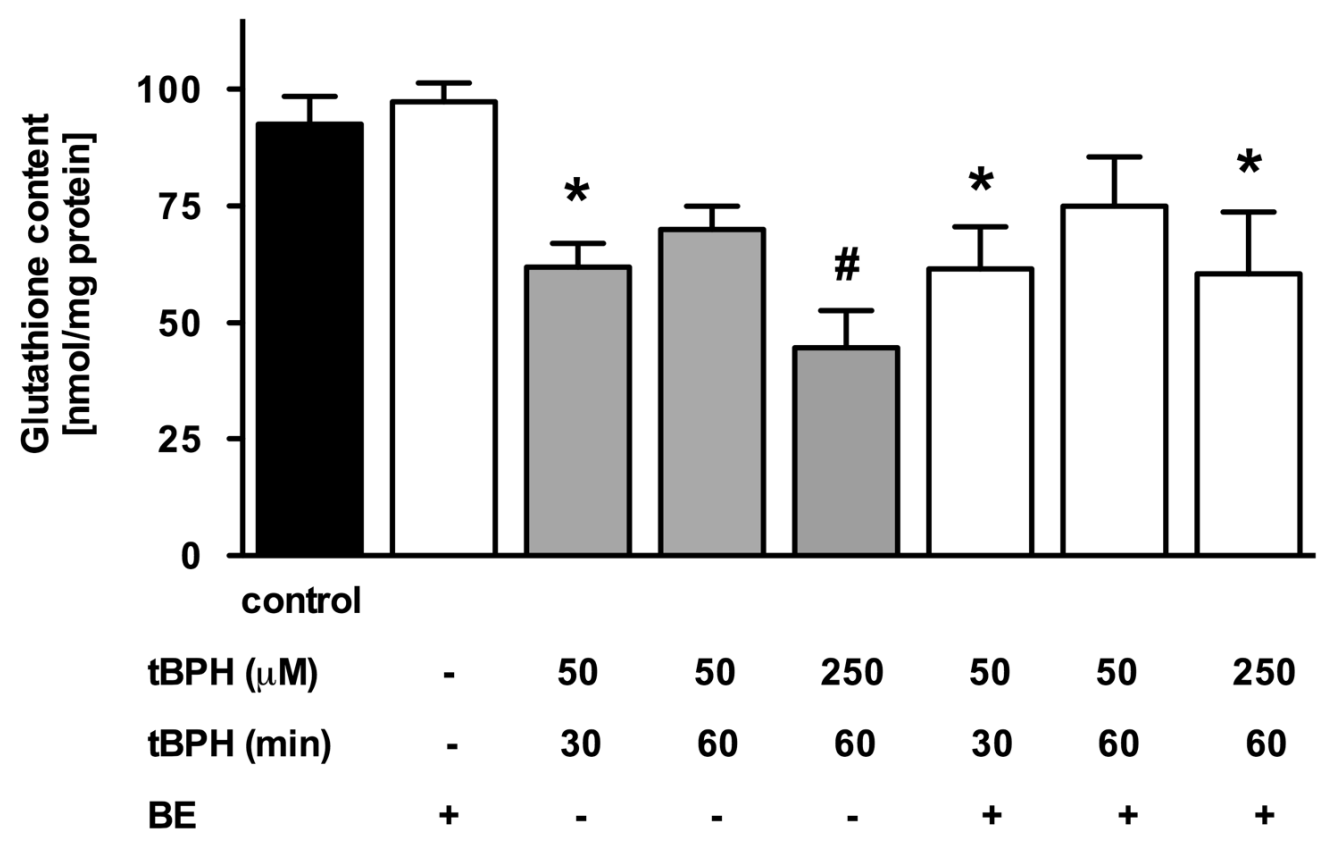

Figure 4: Glutathione content of ChAT-HEK 293 cells treated with $10 \mu \mathrm{M}$ BE for 30 min, followed by exposure to either 50 or $250 \mu \mathrm{M}$ tBHP for $1 \mathrm{~h}$. Data shown are from 3-5 individual experiments (mean $\pm \mathrm{SEM}$ ). $* \mathrm{P} \leq 0.05$, \# $\mathrm{P} \leq 0.001$, vs vehicletreated (control) cells (one-way ANOVA followed by Bonferroni’s Multiple Comparison Test). 
apparent molecular mass near $62 \mathrm{kDa}$. This protein is probably ChAT-SSG because a prominent immunopositive band of identical molecular mass is present when the blots were stripped and re-probed with anti-ChAT antibody. The fact that each of the bands associated with PSSG virtually disappears upon reduction of cell lysates with $100 \mathrm{mM}$ DTT confirms they are disulfides formed from redox regulated proteins with reactive cysteine thiols. The disappearance of higher molecular mass ChATpositive bands from the reduced lysates of cells treated with $\mathrm{tBHP}$ demonstrates that ChAT is a redox regulated protein, as suspected from the cysteine array identified earlier in its crystal structure $(44,45)$. These could be homodimeric or heterodimeric ChAT disulfides.

The greater intensity of the ChAT disulfide band in BE and EtGSH treated cells suggests these chemicals protected against cytotoxicity by preventing further oxidation of ChAT to tri- and poly-sulfides and/or attenuated oxidation of ChAT to its more reactive sulfenic acid derivative (ChAT-S$\mathrm{OH})$.
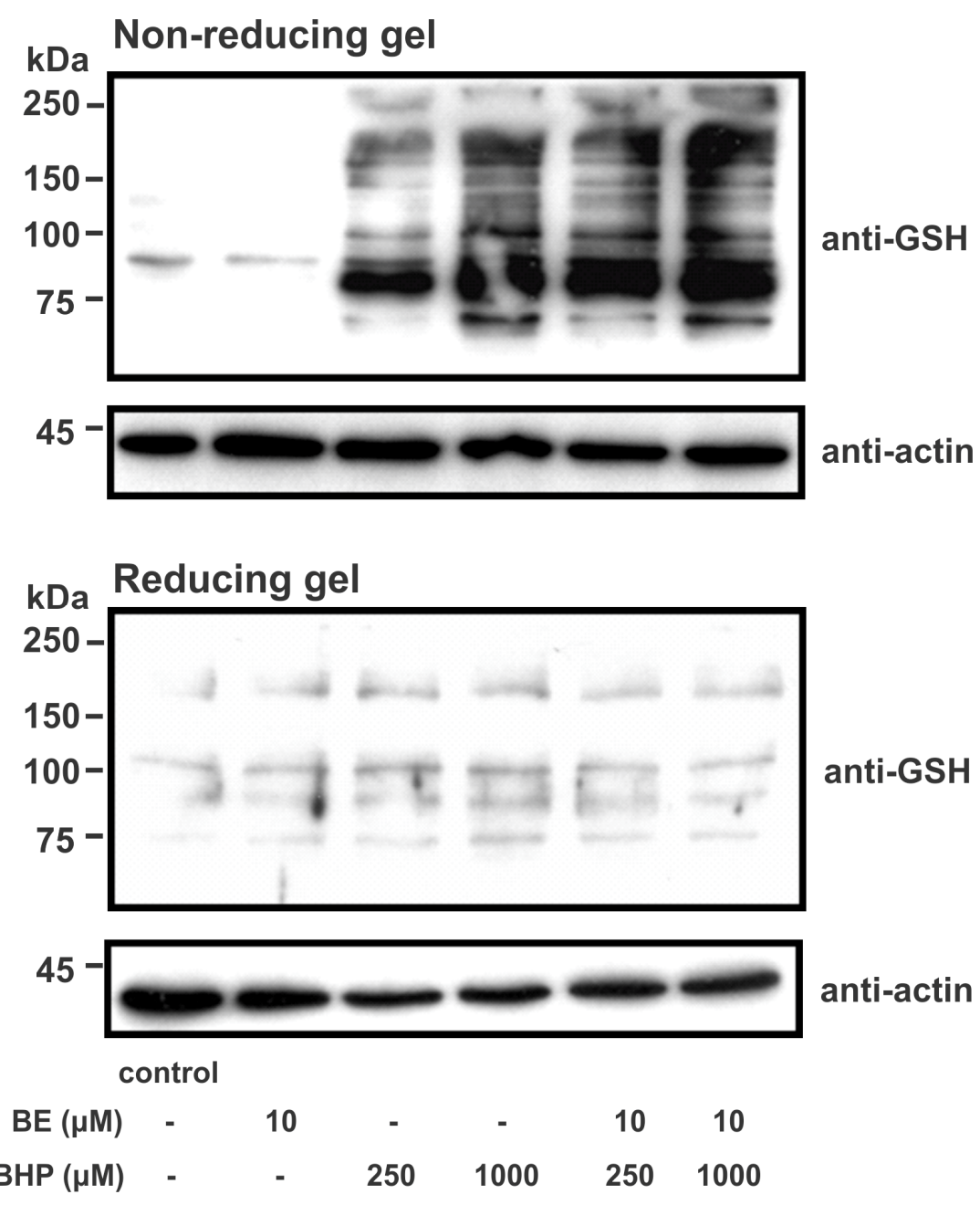

Figure 5: tBHP induces the formation of S-glutathionylated proteins (PSSG). Top Large Panel. PSSG were detected by immunoblotting with anti-GSH antibody following the separation of proteins from cell cytoplasm on one-dimensional nonreducing SDS-PAGE gels; each lane was loaded with $5 \mu \mathrm{g}$ cytoplasmic protein. Cytoplasm was prepared from WT-HEK 293 cells exposed to either $250 \mu \mathrm{M}$ or $1 \mathrm{mM}$ tBHP for $30 \mathrm{~min}$, with or without pre-treatment with $10 \mu \mathrm{M}$ BE for 30 min. Middle Large Panel. As a control, $100 \mu \mathrm{M}$ DTT was added to aliquots of cytoplasm, which reduces PSSG and PSSP. Bottom Panels. Immunoblots were probed with anti- $\beta$-actin antibody to determine if protein loading was uniform. The immunoblots shown are representative of data obtained in three independent experiments. Bottom panels; Lanes: 1, control; 2, $10 \mu \mathrm{M} \mathrm{BE} ; 3,250$ $\mu \mathrm{M}$ tBHP; 4, $1 \mathrm{mM}$ tBHP; 5, $10 \mu \mathrm{M} \mathrm{BE}+250 \mu \mathrm{M}$ tBHP; 6, $10 \mu \mathrm{M} \mathrm{BE}+1 \mathrm{mM}$ tBHP. 


\section{Non-Reduced}

Reduced

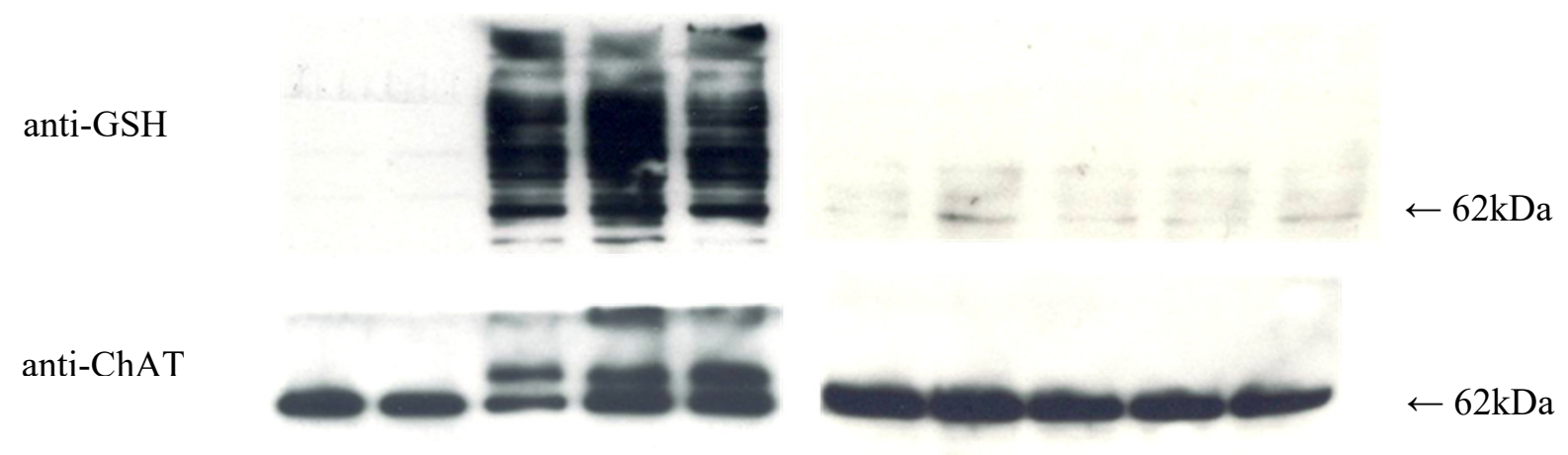

anti- $\beta$-actin

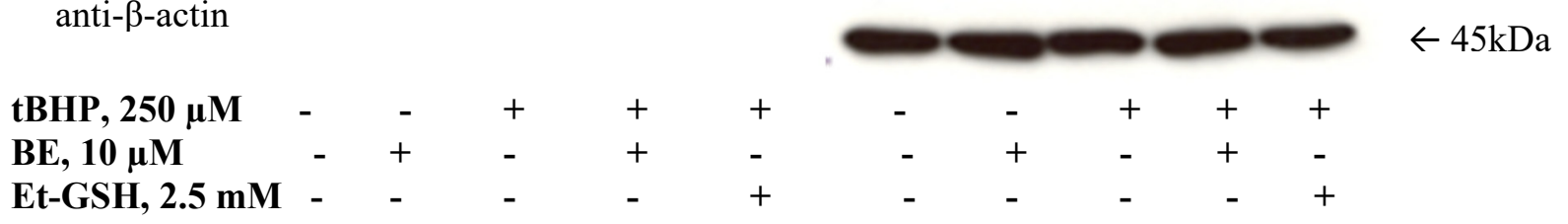

Figure 6: tBHP- $(250 \mu \mathrm{M}, 30 \mathrm{~min})$ initiated formation of PSSG and PSSP including ChAT-SSG (detected by anti-GSH and anti-ChAT) as well as homodimeric or heterodimeric disulfides (ChAT-SSP and/or ChAT-SS-ChAT) detected by anti-ChAT antibody) in cytosol from ChAT-HEK 293 cells. To validate the presence of PSSG and PSSP, an aliquot of each supernatant was reduced with $100 \mathrm{mM}$ DTT upon which disulfide spots disappeared. $\beta$-actin was analyzed as a protein loading control. The constituents of the various incubation mixtures containing ChAT-HEK 293 cells are shown at the bottom of the figure. Ethyl glutathione (EtGSH; $2.5 \mathrm{mM}$ ) was used to increase the intracellular GSH content in some experiments.

\section{Imaging Dynamic Redox Changes in WT-HEK 293 Cells with Transfected roGFP2}

Dynamic changes in the intracellular redox status of WT-HEK 293 cells transiently transfected to express roGFP2, a novel fluorescent reagent that tracks redox changes in the cytoplasm of living cells $(40,41)$, were monitored in real time by confocal laser microscopy following tBHP treatment. Results are presented as images of cells obtained at an emission wavelength of $530 \mathrm{~nm}$ with excitation at both $488 \mathrm{~nm}$ (reduced roPFG2) and $405 \mathrm{~nm}$ (oxidized roGFP2). Changes were quantified by measuring the ratios of fluorescence from excitation at $488 \mathrm{~nm}$ to $405 \mathrm{~nm}$ using pixel counting software (ImageJ software, $\mathrm{NIH}$ ). Changes in the intracellular oxidation state were determined by analyzing roGFP2-expressing WT-HEK 293 cells for $1 \mathrm{~h}$ after addition of $50 \mu \mathrm{M}$ tBHP to medium containing these cells (Figure 7).
Initially, roGFP2 was primarily in its reduced form (preponderance of green compared to red fluorescence at time $=0 \mathrm{~min}$; left panels of Figure 7), an indication of healthy mammalian cells. The ratio of fluorescence intensity at excitation wavelengths of $488 \mathrm{~nm} / 405 \mathrm{~nm}$ was $7.35 \pm 0.54($ mean $\pm \mathrm{SEM}, \mathrm{n}=$ 8 ) prior to the addition of tBHP to the cells (time $=0$ min). roGFP2 expressed in the WT-HEK 293 cells became oxidized upon the addition of $50 \mu \mathrm{M}$ tBHP to the medium, and cells showed membrane blebbing as they underwent oxidative stress (discussed below). Thirty min following the addition of tBHP, the $488 / 405 \mathrm{~nm}$ excitation ratio roGFP2 was decreased by about $55 \%$. As a sign that the cells were recovering, oxidative stress-mediated blebbing was markedly less by $40 \mathrm{~min}$ and disappeared by $60 \mathrm{~min}$ (right panels of Figure 7). However, the cells did not return to their initial redox status at $60 \mathrm{~min}$ of treatment with tBHP. 


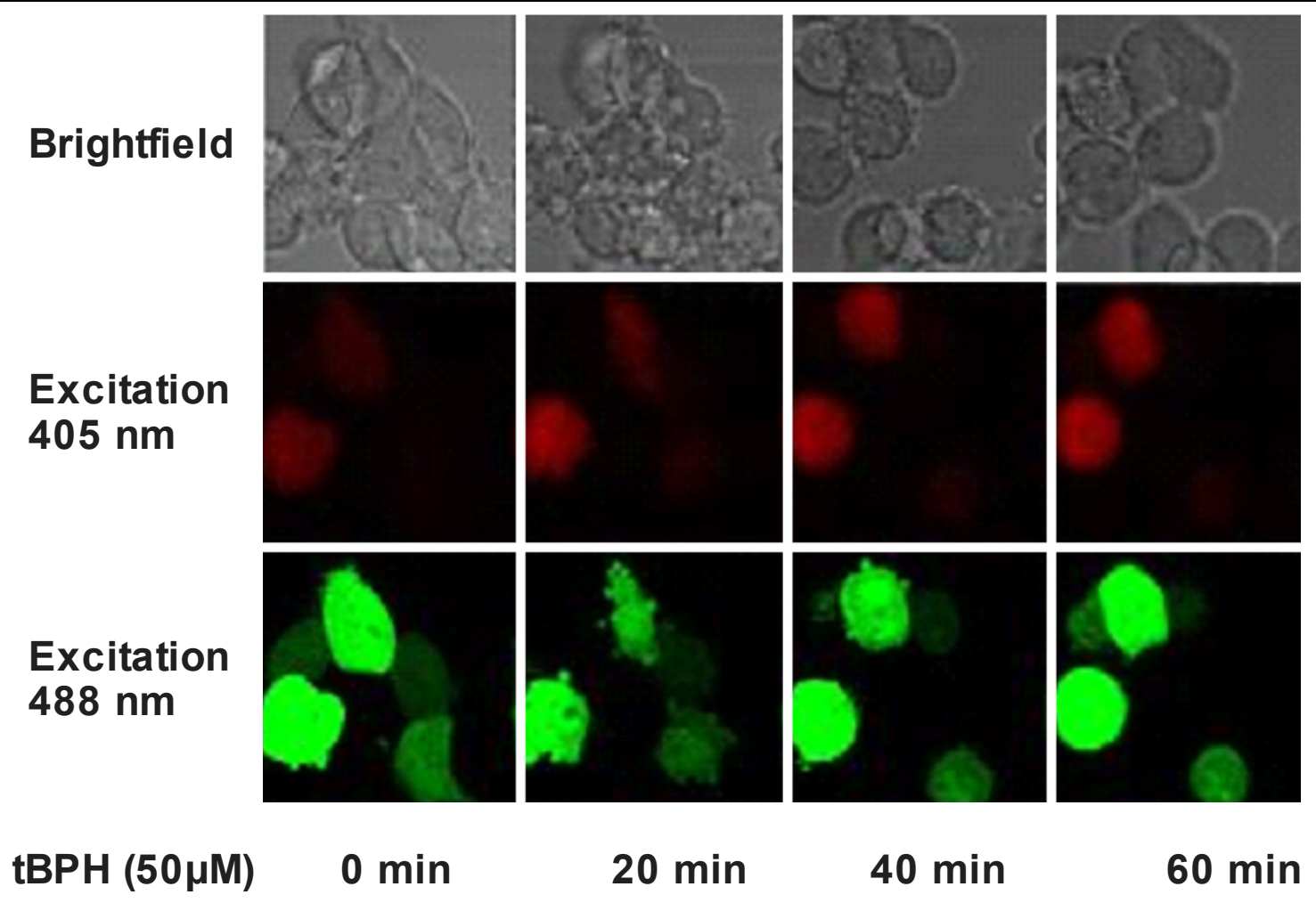

Figure 7: Dynamic intracellular oxidation of WT-HEK 293 cells transiently transfected with roGFP2 following treatment with tBHP $(50 \mu \mathrm{M}$ for $1 \mathrm{~h})$. Cells were visualized with a Zeiss LSM-510 META laser scanning microscope using dual excitation (405 and $488 \mathrm{~nm}$ ), emission of $505 \mathrm{~nm}$. Changes of fluorescence were quantified using pixel counting software. Red was selected as the colour for oxidized roGFP2 and green for the reduced form of this protein.

\section{Attenuation of tBHP-mediated Oxidation by BE in ChAT-HEK 293 Cells Transfected with roGFP2 and Imaged by Confocal Microscopy}

The treatment of roGFP2-expressing ChAT-HEK 293 cells with $10 \mu \mathrm{M}$ BE for 30 min prior to their exposure to $50 \mu \mathrm{M}$ tBHP significantly attenuates intracellular oxidation of roGFP2 (Figure 8). Changes in cellular roGFP2 fluorescence (488/405 $\mathrm{nm}$ excitation ratio, emission at $505 \mathrm{~nm}$ ) demonstrate divergence from BE-treated cells as early as $6 \mathrm{~min}$ after exposure to the oxidative stressor, although the differences did not become significant until $15 \mathrm{~min}$ after tBHP addition. Relatively little oxidation of roGFP2 is associated with tBHP exposure in the BEtreated cells over the $30 \mathrm{~min}$ course of dynamic monitoring. This was not the case with the tBHPtreated cells. There was no indication of roGFP2 reduction in the cells treated only with tBHP over 30 min. More specifically, treatment with $50 \mu \mathrm{M}$ tBHP caused a $44 \%$ decrease of reduced/oxidized roGFP2 fluorescence ratio by $14 \mathrm{~min}$ which increased to $55 \%$ by $30 \mathrm{~min}$. In cells pre-treated with $\mathrm{BE}$, the decrease in reduced/oxidized roGFP2 fluorescence ratio was $16 \%$ at $30 \mathrm{~min}(\mathrm{P} \leq 0.05$ compared to tBHP treatment only). Confocal microscopy also showed that $\mathrm{BE}$ effectively attenuated the cell membrane blebbing induced by tBHP exposure, consistent with its chemoprotectant properties (data not shown)..

\section{Identification of Important Redox-Regulated Proteins in WT-HEK 293 Cells by Mass Spectrometry and Peptide Mass Fingerprinting (MS-PMF) Following Separation by R2D SDS- PAGE}

We chose to use post-translational modifications of reactive cysteine thiol residues of redox-regulated proteins in WT-HEK 293 cells as an endpoint to compare the ability of TCM constituents and defined mixtures to attenuate oxidation of the disulfide proteome by cell permeant tBHP. Initially, we selected 9 protein spots from the redox 2D protein profile of WT-HEK 293 cells for potential identification and "biomarker" use. 


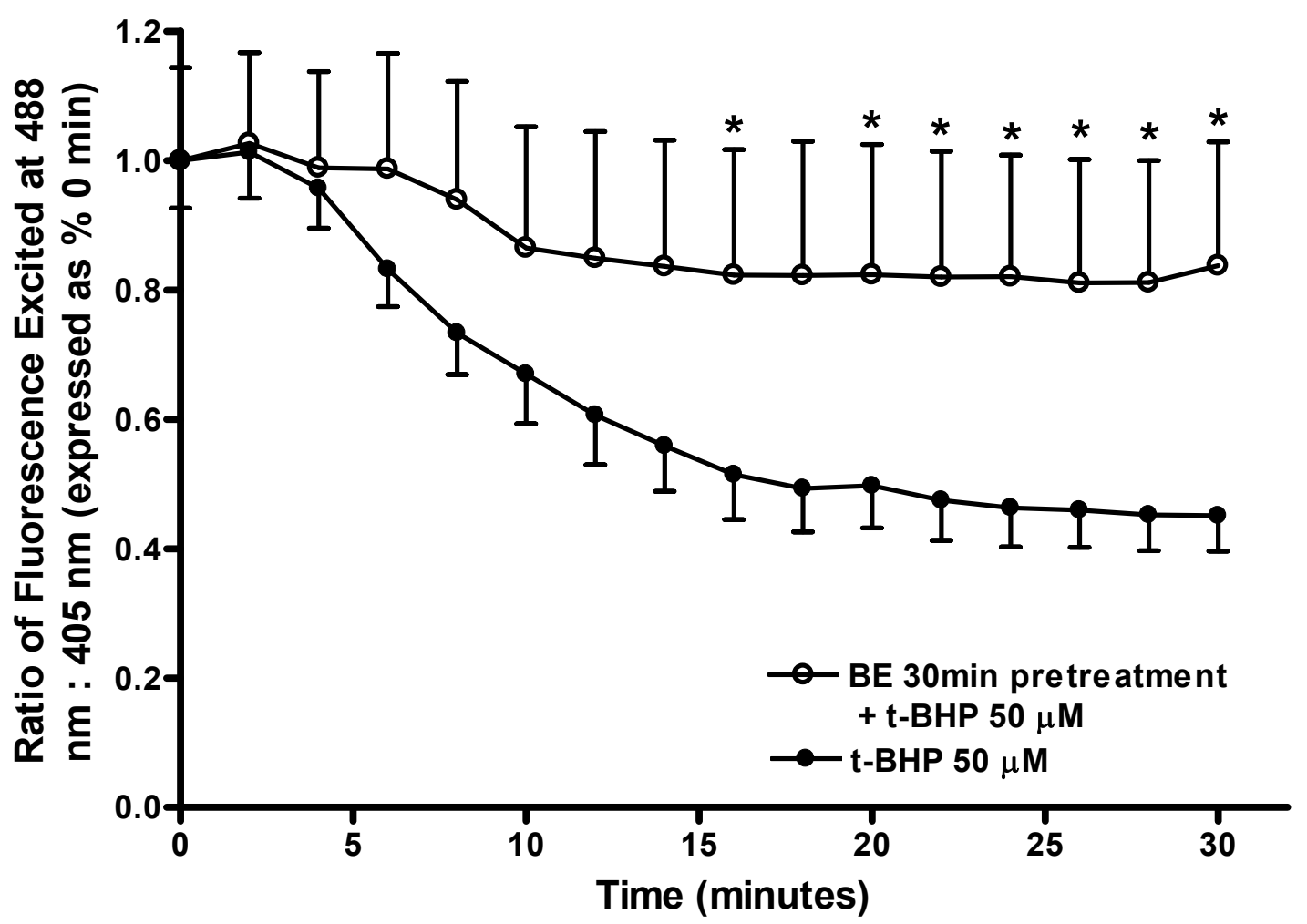

Figure 8: Protective effects of $10 \mu \mathrm{M}$ BE pre-treatment for $30 \mathrm{~min}$ on the intracellular oxidation of roGFP2 in transfected ChAT-HEK 293 cells initiated by $50 \mu \mathrm{M}$ tBHP. Cells were imaged with a Zeiss LSM-510 META laser scanning confocal microscope using dual excitation at 405/488 nm with emission at $505 \mathrm{~nm}$. Changes in the ratio of roGFP2 fluorescence measured at $488 / 405 \mathrm{~nm}$ were quantified by using ImageJ pixel counting software. Data are expressed as the percentage of fluorescence ratio measured in control cells at time $=0 \mathrm{~min}$. The data shown are from $5-8$ individual experiments (mean \pm SEM); * $\leq 0.05$ vs $50 \mu \mathrm{M}$ tBHP treated cells (Student's $t$-test).

However, we subsequently focused on 2 prominent spots (labelled 2 and 3 in Figure 9A) and a minor spot (labelled 1) that were present in all samples from control cells (Fig. 9A). These 3 spots showed dramatic changes upon tBHP treatment, suggesting their importance during oxidative/nitrosative stress.

We positively identified two of these proteins [spots \# 2 and 3] by MS-PMF (Table 1 for spot \# 2) following spot picking and in-gel digestion with sequence grade trypsin, and have tentatively identified the third protein [spot \# 1] (Table 2). The PMF generated for each trypsin-digested protein spot was compared to known peptide mass sequences available on the NCBI database using a search engine (MASCOT, Matrix Science, Boston, MA), and the protein score confidence (PSC) indicated as a percentage for each protein PMF was reported. The PSC is a statistical calculation that compares how closely the acquired PMF compares to known protein peptide sequences and is a measure of the certainty for which the PMF identifies a specific protein. MS-PMF analysis of spots 2 (human prx 2) and 3 (human prx 3) in WT-HEK 293 cells yielded PSC percentages $>90 \%$, whereas that of spot 1 (human prx 1) was only $77 \%$. Six other protein spots that we analyzed did not yield acceptable PSC data demonstrating that in our hands protein identification by R2D-SDS-PAGE-MS is limited to proteins that are expressed in relatively large amounts.

\section{Attenuation of Oxidation of Prx 2 and Prx 3 Thiols by BE Pre-treatment of WT-HEK 293 Cells Exposed to tBHP}

Cytosolic prx 2 and prx 3, and to a lesser extent mitochondrial prx 1, are clearly visible upon R2D SDS-PAGE analysis of cytosol from vehicle-treated WT-HEK 293 control cells (Figure 9A). This is the case for both lysate and cytosol from all untreated or solvent treated WT-HEK 293 cell preparations we 
analyzed by R2D SDS-PAGE. Treatment of these cells with $10 \mu \mathrm{M} \quad \mathrm{BE}$ for $30 \mathrm{~min}$ (Figure 9B) increases the size of the spot for each of these proteins slightly, indicative of more prx disulfide (vs solvent controls). The disulfide-linked dimeric intermediary prx (prx-SS-prx) is present in each case because these disulfides are part of the 2-cysteine prx catalytic recycling mechanism that occurs with prx 1 - prx 4 (46-49). The presence of prx 1, prx 2 and prx 3 in their disulfide-linked dimeric form in untreated WT-HEK 293 cells is related to their physiological role, the reduction of $\mu \mathrm{M}$ concentrations of intracellular $\mathrm{H}_{2} \mathrm{O}_{2}$ (49). Prx protein sulfinic acids are not reduced by DTT so they are not visible as individual spots following R2D SDS-PAGE, but instead run on the prominent diagonal line in the gels that contains all proteins that are not in a disulfide form. Prx 1, 2 and 3 occur as homodimeric disulfides $(45-48)$ that are reduced by DTT in the second dimension of R2D SDS-PAGE. As their molecular weight is halved (protein disulfide to 2 molecules protein thiol), these prxs are visible as single spots below and to the right of the prominent diagonal line that is formed by the mass of cellular non-disulfide, non-redox regulated proteins.

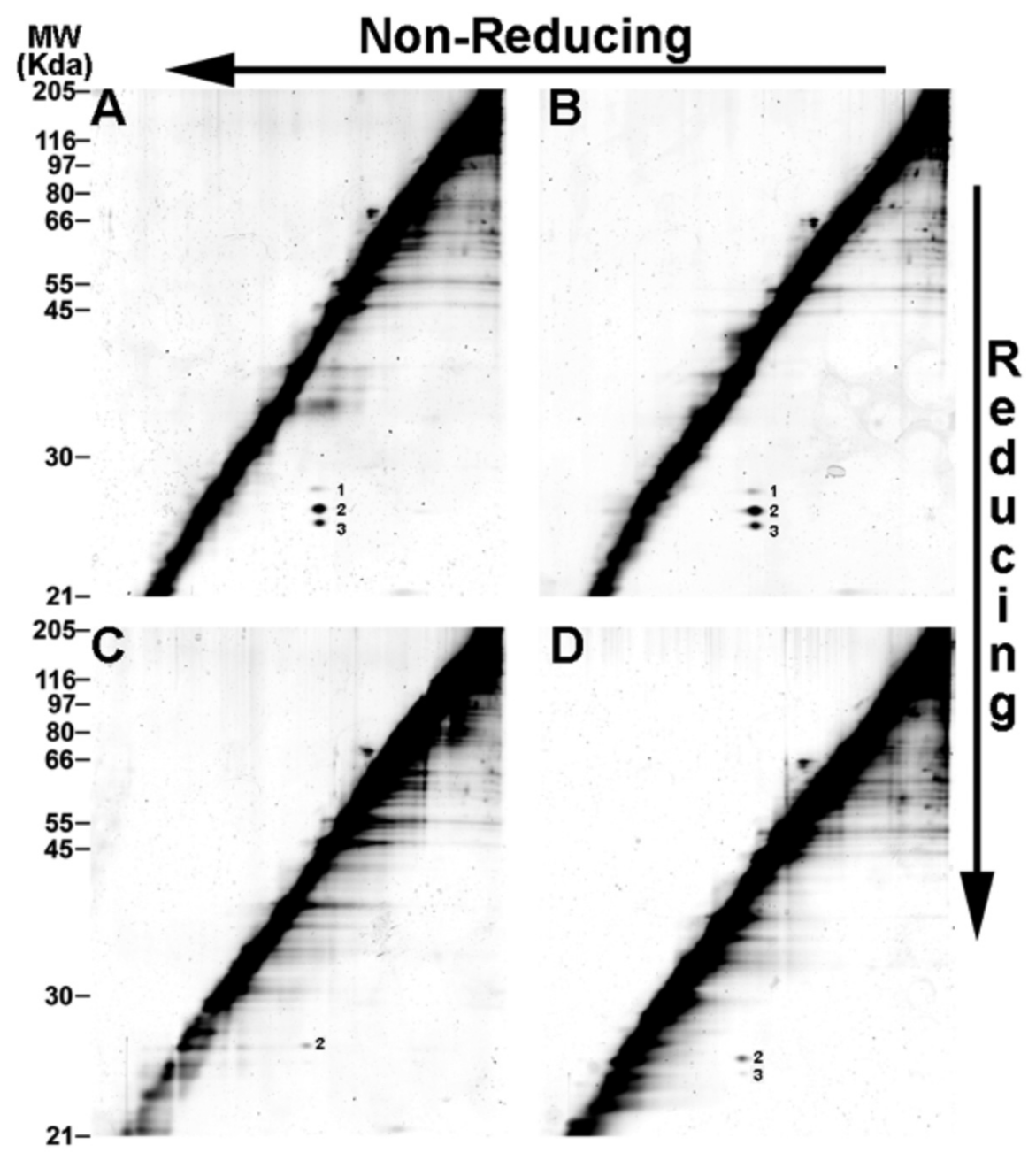

Figure 9: The protective effects of BE on tBHP-mediated intracellular oxidation of cytosol from WT-HEK cells was evaluated by R2D SDS-PAGE coupled with silver staining of gels. A = vehicle ( $0.2 \%$ DMSO)-treated control cells; $\mathrm{B}=$ cells treated with $10 \mu \mathrm{M} \mathrm{BE}$ for $30 \mathrm{~min}$; $\mathrm{C}=$ cells treated with $50 \mu \mathrm{M}$ tBHP for $30 \mathrm{~min}$; and $\mathrm{D}=$ cells treated with $10 \mu \mathrm{M}$ BE for 30 min prior to a 30 min treatment with $50 \mu \mathrm{M}$ tBHP. Cytosol was isolated from cells and $75 \mu \mathrm{g}$ protein analyzed for each treatment group. All gels were run in triplicate and sets of gels were silver stained simultaneously, with the experiment repeated three separate times with different cell cultures (i.e. a total of 9 gels were analyzed for each treatment group). All spots marked were present on each gel in the respective treatment groups. 
Table 1: Mass spectrometric peptide mass fingerprinting (MS PMF) sequence data for protein spot 2 from WT-HEK 293 cells. Data from MASCOT ${ }^{\circledR}$, a search engine which compared the PMF of tryptic digests of protein spot 2 against an NCBI database of known protein peptide masses used to determine the identity of the disulfide bonded protein separated by redox 2D-gels. Protein identified was peroxiredoxin 2 isoform a (Homo sapiens), a major redox-regulated protein in lymphocytes.

\begin{tabular}{|c|c|c|c|c|c|c|}
\hline \multicolumn{7}{|c|}{ Peptide Information } \\
\hline $\begin{array}{l}\text { Calc. } \\
\text { Mass }\end{array}$ & $\begin{array}{c}\text { Observ } \\
\text { Mass }\end{array}$ & \pm da & $\pm \mathbf{p p m}$ & $\begin{array}{l}\text { Start } \\
\text { Seq. }\end{array}$ & $\begin{array}{l}\text { End } \\
\text { Seq. }\end{array}$ & Sequence \\
\hline 765.39 & 765.39 & -0.0024 & -3 & 62 & 67 & AEDFRK \\
\hline 789.41 & 789.41 & -0.0012 & -2 & 151 & 157 & SVDEALR \\
\hline 862.50 & 862.49 & -0.0108 & -13 & 128 & 135 & GFIIDGK \\
\hline 924.44 & 924.44 & -0.0003 & 0 & 120 & 127 & TDEGIAYR \\
\hline 972.55 & 972.55 & -0.0049 & -5 & 8 & 16 & IGKPAPDFK \\
\hline 1023.54 & 1023.54 & 0.00 & 1 & 111 & 119 & LSEDYGVLK \\
\hline 1179.64 & 1179.63 & -0.0085 & -7 & 110 & 119 & RLSEDYGVLK \\
\hline 1211.67 & 1211.67 & -0.0039 & -3 & 140 & 150 & QITVNDLPVGR \\
\hline 1734.97 & 1734.95 & -0.0268 & -15 & 93 & 109 & EGGLGPLNIPLLADVTR \\
\hline 1863.07 & 1863.02 & -0.0523 & -28 & 92 & 109 & KEGGLGPLNIPLLADVTR \\
\hline
\end{tabular}

Table 2: Proteins that form intermolecular disulfide bonds during tBHP-induced oxidative stress in WT-HEK 293 cells separated by R2D SDS-PAGE and identified by MS-PMF.

\begin{tabular}{cccccc}
\hline $\begin{array}{c}\text { Protein } \\
\text { Spot }\end{array}$ & Protein Name & Accession No. & $\begin{array}{c}\text { Protein } \\
\text { Score \% }\end{array}$ & $\begin{array}{c}\text { Protein } \\
\text { MW }\end{array}$ & $\begin{array}{c}\text { Protein } \\
\text { PI }\end{array}$ \\
\hline 2 & Peroxiredoxin 2 isoform a & gi|55959887 & 90.18 & 19134.7 & 6.41 \\
3 & $\begin{array}{c}\text { [Homo sapiens] } \\
\text { Peroxiredoxin 3, isoform CRA_c } \\
\text { [Homo sapiens] }\end{array}$ & gi|32189392 & 100 & $\mathbf{2 2 0 4 9 . 3}$ & 5.66 \\
Peroxiredoxin 1 & gi|119569783 & 76.99 & 11157.8 & 6.06 \\
\hline
\end{tabular}

Treatment of cells with $50 \mu \mathrm{M}$ tBHP for $30 \mathrm{~min}$ (Figure 9C) resulted in the disappearance of prx 1 and prx 3 and a marked diminution of prx 2 . This is due to the increased formation of prx sulfinic acids at the expense of prx disulfide-linked dimers (48), a reaction termed hyperoxidation. Pretreatment of the cells with $10 \mu \mathrm{M}$ BE for $30 \mathrm{~min}$ before tBHP exposure partially attenuated the effects of this oxidative stressor. Thus, the prx 2 spot is more intense than in cells treated with tBHP alone, and prx 3 becomes visible in BE-pretreated cells treated with tBPH but not in cells treated with tBPH alone.

Effect of Treatment of WT-HEK 293 Cells with Schisanhenol (Sal) or Two Defined Equimolar TCM Mixtures on the Disulfide Proteome, With or Without Subsequent Exposure to tBHP

The effects of pre-treatment of WT-HEK 293 cells with Sal $(20$ and $100 \mu \mathrm{M})$, MIX $1(20$ and $100 \mu \mathrm{M})$ or MIX-S $(20 \mu \mathrm{M})$ on the disulfide proteome are shown in Figure 10. The solvent controls for two different sets of experiments (Figures 9A and 10A) are very similar; prx 2 (most prominent spot), prx 3 and prx 1 (least prominent spot) are clearly visible in each case. Pre-treatment with Sal and MIX showed an apparent dose response in that spots formed by the reduction of the dimeric disulfide forms of prx 2 and prx 3 are present in slightly higher concentrations (larger spots) in cells treated with 100 vs $20 \mu \mathrm{M}$ Sal (Figures 10C vs 10B); and with 100 vs $20 \mu \mathrm{M}$ MIX (Figures $10 \mathrm{E}$ vs 10D). In addition, the prx 2 spot appears slightly larger in $20 \mu \mathrm{M}$ MIX-S vs $20 \mu \mathrm{M}$ MIX treated cells (Figures 10F vs 10D) but is not as intense. Thus, not even a slight difference can be inferred between these two treatment regimens. In common, each of the TCM treatments evaluated reduces the cytosolic compartment of HEK 293 cells, an observation previously made with BE, Cro, Res and Sal and these two TCM mixtures in Jurkat E6.1 cells (11). 


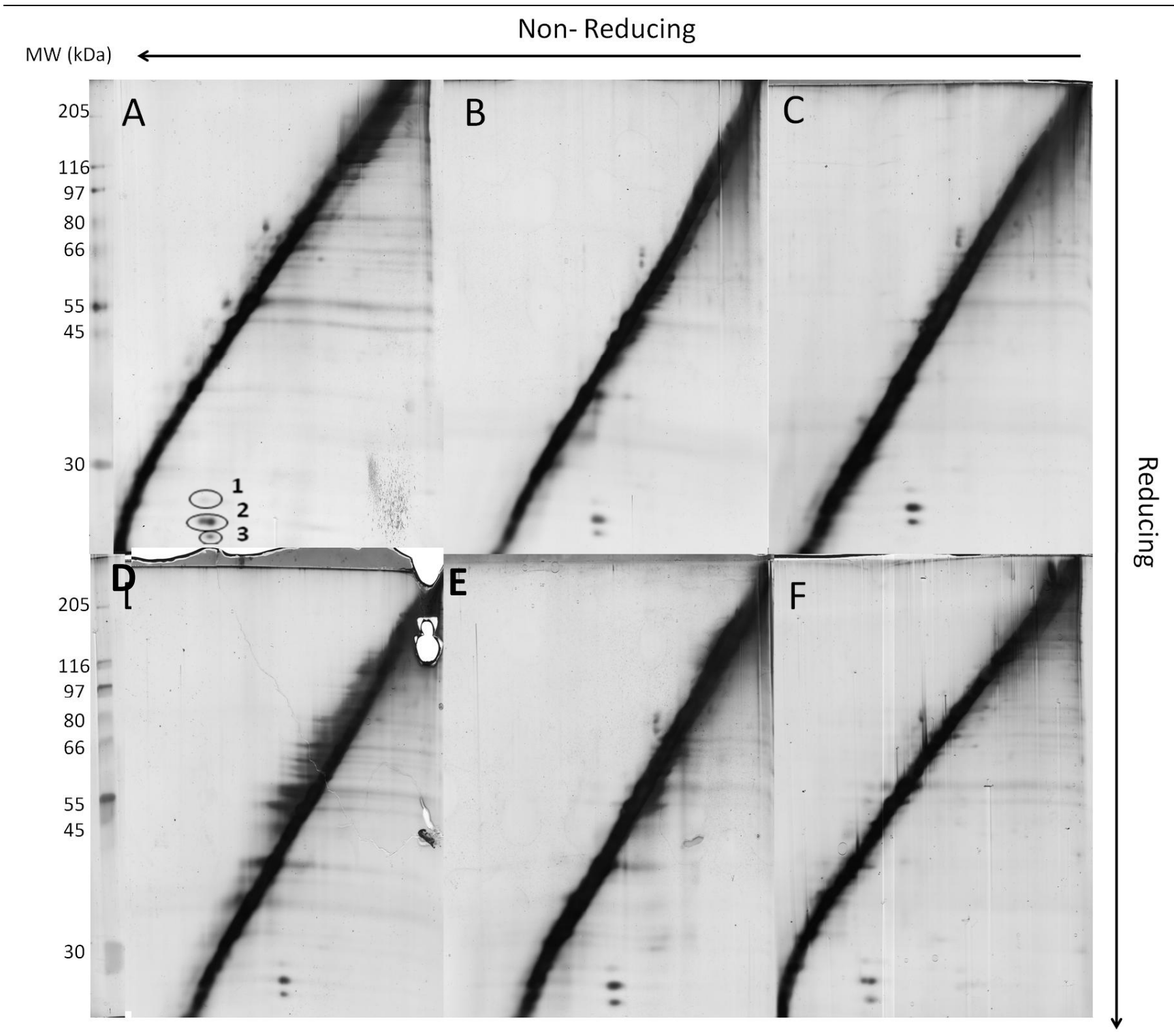

Figure 10. Effects of antioxidant pre-treatments on the disulfide proteome of WT-HEK 293 cells analyzed by redox 2D PAGE. Cells were treated with $0.2 \%$ DMSO (solvent control) or the various TCM treatments for 30 min. Cytosolic proteins $(75 \mu \mathrm{g})$ were loaded onto each gel. A. DMSO control, B. SAL $20 \mu \mathrm{M}$, C. SAL $100 \mu \mathrm{M}$, D. MIX $20 \mu \mathrm{M}$, E. MIX $100 \mu \mathrm{M}, \mathrm{F}$. MIX-S $20 \mu \mathrm{M}$. All gels were run in triplicate from three different cell cultures. Proteins spots marked 1, 2 and 3 were present on each run and were identified by mass spectrometry to be peroxiredoxins (prx) 1,2 and 3, respectively (Table 2).

As opposed to the R2D SDS-PAGE gels that were prepared for the analysis of cytosol from WTHEK 293 cells treated only with TCM constituents that contained prominent spots for prx 2 and prx 3 (Figure 10B-10F), gels from WT-HEK 293 cells treated in the same experiments with $50 \mu \mathrm{M}$ tBHP contained a much less intense spot for prx 2 and no spots for prx 3 or prx 1 (Figure 11A), equivalent to data with a different cell culture shown in Figure 9C.
In cells treated with TCM regimen first and then with tBHP, minor chemoprotection was observed with some (Figures 11C-11F) but not all of the treatments (Figure 11B). The prx 2 spot is somewhat more intense in cells treated with $100 \mu \mathrm{M}$ (Figure 11C) compared to $20 \mu \mathrm{M} \mathrm{Sal}$ (Figure 11B) and 100 $\mu \mathrm{M}$ (Figure 11E) compared to $20 \mu \mathrm{M}$ MIX (Figure 11D). Of significance to our interest in defined TCM mixtures as chemoprotectants, the prx 2 spot is more intense with $20 \mu \mathrm{M}$ MIX (Figure 11D) and $20 \mu \mathrm{M}$ 
MIX-S (Figure 11F) than with $20 \mu \mathrm{M}$ Sal (Figure 11B). Although these changes are not dramatic, they were observed in each of the separate experiments $(n=9$ gels for each treatment we conducted.

\section{DISCUSSION}

Experiments described in this paper were designed to evaluate the ability of single TCM constituents (Sal, BE, Cro or Res, with emphasis on understudied Sal and well-studied BE (24)) with known chemoprotectant properties at nontoxic concentrations (16-18,20,24,25,28), and of two novel defined mixtures with lower cytotoxicity than individual constituents in experiments performed in our laboratory with Jurkat E6.1 cells (11), to attenuate tBHP-mediated oxidative stress in WTHEK 293 cells and ChAT-HEK 293 cells.

The individual chemicals were chosen because their structures and chemical classes are divergent (Figure 1A-1D) as are some of their mechanisms of chemoprotection against oxidative and nitrosative stress (20,21,24-28). These experiments have limitations because chemoprotection in vitro can vary markedly from that in vivo because of differences in absorption, distribution, metabolism and elimination (i.e. pharmacokinetics). This is also an area where carefully chosen TCM mixtures can provide superior chemoprotection compared to single TCM constituents while minimizing the adverse effects often associated with administration of complex TCM prescriptions (50).

tBHP is a membrane penetrable alkyl hydroperoxide reagent widely used to induce oxidative stress in cells (51-54). The toxicity of tBHP is attributed to the generation of butoxyl radicals due to the Fenton reaction which can subsequently initiate lipid peroxidation, modify cellular lipids and proteins

(Figures 9-11), affect cell integrity and signalling, and form covalent bonds with cellular molecules resulting in cell injury. Alternatively, the free radicals produced from $\mathrm{ABHP}$ (butoxyl and other ROS, including $\mathrm{H}_{2} \mathrm{O}_{2}$ and $\mathrm{NO}$, an RNS) can directly deplete intracellular thiols and GSH (Figure 4), thereby decreasing the capacity of nonenzymatic antioxidant systems and enzymatic radical detoxication (for example by GSH transferases and GSH peroxidases), eventually leading to cell death. An interesting phenomenon of tBHP toxicity in hepatocytes and other cells is plasma membrane bleb formation (blebbing). We observed this phenomenon by confocal microscopy in WT- HEK 293 cells (Figure 7) that had been treated with tBHP. Bleb formation is due to the oxidative modification of free thiol groups in cytoskeletal proteins (54), including actin which contains a reactive cysteine thiol moiety (Cys374), forms a S-glutathionylated derivative and is redox-regulated $(55,56)$. Of importance, tBHPmediated blebbing was prevented in WT- HEK 293 cells (Figure 7) by pre-treatment with $10 \mu \mathrm{M} \mathrm{BE}$, an excellent example of chemoprotection.

$\mathrm{LDH}$ is a cytosolic enzyme whose release into the cell medium (in vitro) or blood (in vivo) is a sensitive assay for cytotoxicity. Loss of cellular LDH due to impaired cell membrane integrity is an early indicator for cell death by both apoptosis and necrosis. Of the TCM antioxidants evaluated here (Figures 2 and 3), only treatment with $100 \mu \mathrm{M}$ Sal for $30 \mathrm{~min}$ caused significant cytotoxicity to WTHEK 293 cells (23\% LDH release). Treatment of cells with 10 or $20 \mu \mathrm{M}$ Sal did not cause cytotoxicity (Figure 2). All TCM treatments attenuated cytotoxicity due to exposure to $250 \mu \mathrm{M}$ tBHP but there were no significant differences between Sal and the two mixtures, MIX (equimolar Sal, Cro, BE, Res) and MIX-S (equimolar Cro, BE, Res) in this regard.

ChAT is a critical enzyme that catalyzes the synthesis of the neurotransmitter acetylcholine. It has an unusually high number of cysteine amino acid residues (3.2\% of total) and is a probable site for oxidative stress-mediated neurotoxicity $(14,15,44,45)$. The availability of stably-transfected ChAT-expressing HEK 293 cells (14) allowed us to compare tBHP toxicity in ChAT-HEK 293 to WTHEK 293 cells (Figure 3). Vehicle-treated ChATexpressing cells released more LDH into the medium than did WT-HEK 293 cells, but this cytotoxicity was decreased to control values by treatment of ChAT-HEK 293 cells with either 5 or $10 \mu \mathrm{M}$ BE. Upon exposure to $250 \mu \mathrm{M}$ tBHP for $3 \mathrm{~h}$, the ChATHEK 293 cells released twice as much LDH into the medium as did the WT-HEK 293 cells. Attenuation of tBHP-mediated cytotoxicity by pre-treatment of the cells with $10 \mu \mathrm{M}$ BE was significantly less effective in ChAT-expressing than it was in WTHEK 293 cells (Figure 3).

The tripeptide, GSH ( $\gamma$-Glu-Cys-Gly) is present at high concentrations $(0.5-10 \mathrm{mM})$ in mammalian cells. It represents approximately $95 \%$ of total nonprotein sulfhydryls and is the major modulator of cellular redox equilibrium (57). 


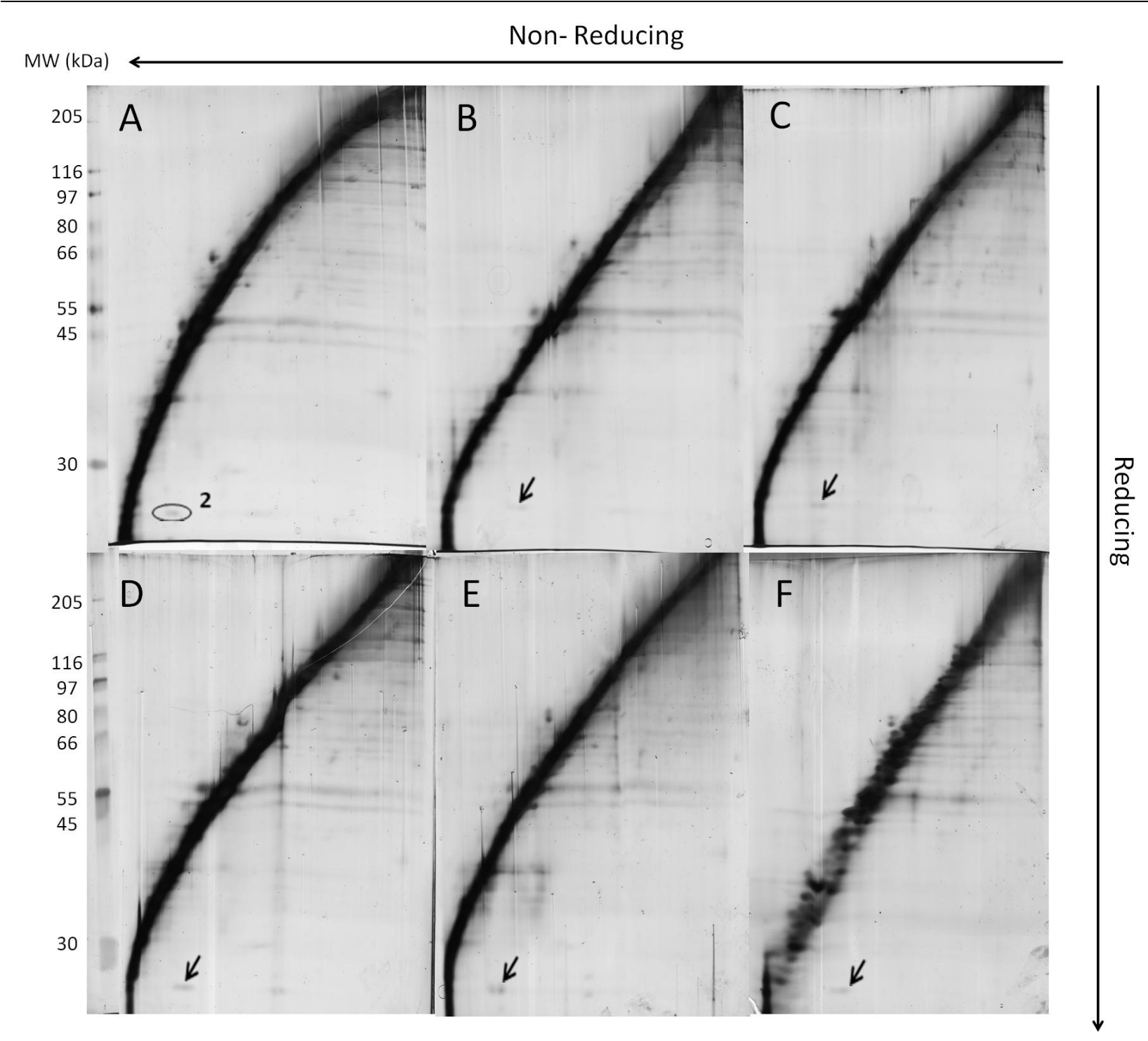

Figure 11. Effects of $50 \mu \mathrm{M}$ tBHP treatment with or without TCM pre-treatment on the disulfide proteome of WT-HEK 293 cells analyzed by redox 2D SDS PAGE. Cells were pre-treated with each of the antioxidants for 30 min followed by tBHP for 30 min. Cytosolic proteins $(75 \mu \mathrm{g})$ were loaded onto each gel. A. tBHP $50 \mu \mathrm{M}$, B. SAL $20 \mu \mathrm{M}+\mathrm{tBHP} 50 \mu \mathrm{M}, \mathrm{C}$. SAL $100 \mu \mathrm{M}+$ tBHP $50 \mu \mathrm{M}$, D. MIX $20 \mu \mathrm{M}+$ tBHP $50 \mu \mathrm{M}$, E. MIX $100 \mu \mathrm{M}+\mathrm{tBHP} 50 \mu \mathrm{M}$, and F. MIX-S $20 \mu \mathrm{M}+$ tBHP $50 \mu \mathrm{M}$. All gels were run in triplicate with cells from three individual cell cultures. Protein spot 2, designated by arrows in $\mathrm{B}$ through $\mathrm{F}$ was identified as peroxiredoxin 2 (Tables 1 and 2).

The cytoplasmic ratio of reduced to oxidized glutathione (GSH/GSSG) in healthy cells approaches 100/1, and steady state is maintained by NADPH-dependent GSH reductase (57). Under conditions of moderate oxidative stress, a limited amount of GSH is converted to GSSG which alters the GSH/GSSH ratio as well as cellular redox status. In this study, we observed rapid, concentrationdependent GSH depletion after exposure of WTHEK 293 cells to increasing concentrations (10 to $250 \mu \mathrm{M}$ ) of tBHP (data not shown). A similar concentration-dependent depletion of GSH was noted in ChAT-HEK 293 cells $(20 \%$ at $50 \mu \mathrm{M}, 50 \%$ at $250 \mu \mathrm{M}$ tBHP for $60 \mathrm{~min}$; Figure 4). A significant difference between the HEK cell types studied is that $10 \mu \mathrm{M} \mathrm{BE}$ was very effective at attenuating GSH depletion in WT cells but not in ChAT-HEK 293 cells, which appear to be under more oxidative stress (Figure 4). Of importance, treatment with BE (10 $\mu \mathrm{M})$ for $24 \mathrm{~h}$ was less effective than $30 \mathrm{~min}$ treatment in preventing GSH depletion in WT cells. This emphasizes the importance of pharmacokinetics in 
selection of TCM agents and mixtures for in vivo (including human) studies. As mentioned above, BE is rapidly eliminated due to conjugation and active transport into urine. Thus, repeated administration is required for rapidly eliminated chemicals such as BE to be effective chemoprotectants in vivo although preparation of more-slowly metabolized derivatives, such as methoxyl ethers increases the half-life of polyphenols (58).

Proteins with ionized cysteine thiol residues at physiological $\mathrm{pH}$ (approximately 400 such proteins currently known) are more readily oxidized to their PS-OH derivatives than unionized protein thiols under conditions of mild and moderate oxidative or nitrosative stress $(8,29,30)$. Post-translational modification at reactive cysteine thiols forms products that are biologically reducible (PSSG, PSSG-NO; PSSP; P'SSP). However, further oxidation leads to products that cannot be readily reduced enzymatically, including protein sulfinic acids $\left(\mathrm{PSO}_{2} \mathrm{H}\right)$, protein sulfonic acids $\left(\mathrm{PSO}_{3} \mathrm{H}\right)$ and polymeric protein disulfides ((PSSPSSP'SSPS')x). Formation of these latter products frequently occurs concomitantly with severe cytotoxicity and cell death. Post-translational reactions at ionized cysteine thiol are the basis for selective redox regulation of many proteins including the prxs $(7,47,48)$. We monitored S-glutathionylation of proteins subsequent to treatment with tBHP in both WT(Figure 5) and ChAT-HEK 293 cells (Figure 6) by non-reductive SDS-PAGE with detection of PSSG by a monoclonal antibody to GSH. In short, many Sglutathionylated proteins were formed during exposure to tBHP, verified by reduction of aliquots of cell lysates or cytosol with $100 \mathrm{mM}$ DTT upon which anti-GSH staining was obliterated (Figure 6).

A more sophisticated approach was possible with tBHP-oxidized ChAT-HEK 293 cells (Figure 6) because of the availability of anti-ChAT antibody (15). Rylett and her colleagues postulated that ChAT is a redox-regulated protein from their resolved crystal structure of human ChAT $(44,45)$. Analysis of the protein crystals identified a cysteine tetrad at the active site of the enzyme. As ionized cysteine thiol is a common component of the active site of enzymes, they predicted that ChAT is redoxregulated (45). The experiments reported here confirm this fact. Under conditions of oxidative stress (Figure 6) ChAT is converted to both ChATSS-G, a prominent band at $62 \mathrm{kDa}$ which stained both with anti-GSH and anti-ChAT antibodies, and protein disulfides, demonstrated by disappearance of higher molecular wt bands than $62 \mathrm{kDa}$ that stained with anti-ChAT upon reduction with DTT. Whether these are monomeric (ChAT-SS-ChAT) or dimeric ChAT disulfides (ChAT-SS-P) is unknown.

Real-time visualization of intracellular redox status of tBHP treated WT-HEK 293 cells (Figure 7) and ChAT-HEK 293 cells (Figure 8) via confocal microscopy was made possible by monitoring oxidation-reduction of the disulfide-dependent reporter protein, roGFP2 $(40,41)$. This novel technology allowed us to monitor oxidation of the cell cytosol and blebbing concomitantly. The fact that blebbing disappeared before the cells returned to their initial redox equilibrium indicates there is a threshold for oxidative stress-induced blebbing in HEK 293 cells transiently transfected with roGFP2. Of importance, BE $(10 \mu \mathrm{M})$ is able to prevent tBHP$(50 \mu \mathrm{M})$ mediated oxidation of cytosolic roGFP2 in HEK 293 cells over the $30 \mathrm{~min}$ these effects were monitored (Figure 8). Part of this BE effect may result from its ability to decrease intracellular $\mathrm{H}_{2} \mathrm{O}_{2}$ concentrations (20).

Because PSSG and PSSP were formed in abundance during tBHP treatment of WT- (Figure 5) and ChAT-HEK 293 cells (Figure 6) we required a more sensitive technique for the analysis of PSSP, i.e., the disulfide proteome $(7,35,36,42)$. We utilized reduced two-dimensional SDS-PAGE (R2D SDSPAGE) for this purpose (Figure 9). This technique is also called non-reducing/reducing "diagonal" PAGE and is an established method to resolve cytoplasmic proteins that undergo disulfide bond formation following oxidative stress (42). After staining the gel, proteins that do not contain any disulfide bond form a prominent diagonal line; proteins that are covalently linked by an intermolecular disulfide bond are found below the diagonal line (right side) and proteins that form intramolecular disulfide bonds are found slightly above the diagonal line (left side) formed by unmodified proteins. We noted more than 25 homodimeric or heterodimeric protein disulfides formed in WT-HEK 293 cells exposed to tBHP throughout the course of our study. Important for our purposes, tBHP always resulted in the disappearance or decreased size of two prominent cytosolic proteins, prx 2 and prx 3 upon R2D SDS-PAGE analysis. We identified these proteins using MALDIMS FSM (Table 1). The prxs exist, in part, as homodimeric protein disulfides, the reason they are resolved upon R2D SDS-PAGE. We selected prx 2 and prx 3 as our primary biomarkers for monitoring change in the disulfide proteome because they: i) are 
prominent protein spots present in every R2D SDSPAGE analysis of WT-HEK 293 cell lysate we have ever run; ii) show dramatic changes (i.e. disappear) as a result of oxidative stress-mediated hyperoxidation; iii) are well characterized and known to be localized in the cytosol of cells $(46,48)$; and iv) we confirmed their identity by MS-FSM analysis of WT-HEK 293 cells.

Based on changes in the size or intensity of silver-stained spots for prx 2 and prx 3 (and to a more limited extent, prx 1) in the R2D SDS-PAGE analysis of the $50 \mu \mathrm{M}$-tBHP oxidized disulfide proteome of WT-HEK-293 cells, we conclude that at equimolar concentrations, MIX-S (equimolar BE, Cro, Res) and MIX (equimolar Sal, BE, Cro, Res) are as protective or even slightly more cytoprotective than the single TCM constituents, Sal (Figure 11) or BE (Figure 9). Of significance, each TCM treatment evaluated did provide chemoprotection from oxidation of the disulfide proteome which is often a critical early step in cytotoxicity (e.g. cell blebbing) (54-56).

We are especially interested in the chemoprotection potential of Sal, a poorly studied dibenzocyclooctene lignin isolated from Schisandra rubriflora and characterized in the Chen laboratory $(57,58)$. Here, we directly evaluated several properties of pure $(>99 \%)$ Sal in HEK 293 cells in culture. In this regard, Sal was cytotoxic at $100 \mu \mathrm{M}$ (caused release of approximately $20 \%$ intracellular $\mathrm{LDH}$ ) but not at 10 or $20 \mu \mathrm{M}$ (Figure 2). It significantly attenuated the cytotoxicity of $250 \mu \mathrm{M}$ tBHP at 10,20 or $100 \mu \mathrm{M}$ showing optimal protection at $20 \mu \mathrm{M}$ (Figure 3). Sal $(20 \mu \mathrm{M})$ attenuated tBHP-mediated oxidation of the disulfide proteome but not dramatically. We also evaluated the effectiveness of Sal as part of an equimolar mixture (Sal, BE, Cro, Res) compared to an equimolar mixture containing only BE, Cro and Res in this study. These two mixtures were almost equivalent in their ability to attenuate the cytotoxicity, lipid peroxidation, protein carbonylation, and hyperoxidation of prx 2 initiated by $400 \mu \mathrm{M}$ SMX$\mathrm{NHOH}$ in Jurkat E6.1 cells (11).

In a previous investigation (11), we showed that MIX and MIX-S are slightly more effective in attenuating hyperoxidation of intracellular prx 2 in Jurkat E6.1 cells exposed to SMX-NHOH than are equal concentrations of Sal, BE, Cro or Res.

In concert the results from these two studies suggest that defined mixtures of well characterized TCM constituents might serve as chemoprotectants for diseases caused or promoted by ROS/RNS. In this regard, such mixtures might best serve as complementary or adjunct therapy.

There are two potential advantages of welldefined TCM mixtures over single TCM constituents in therapy. First, potent compounds that exert their chemoprotective properties via different molecular mechanisms are likely to be more active in combination that alone. Second, compounds with different pharmacokinetic properties might be combined to increase half-life and prolong desired pharmacodynamic effect(s). Sal is an example of a TCM constituent with prolonged half-life, and prolonged biological activity. Sal contains 6 phenolic hydroxyl groups, which are responsible for antioxidant activity. However, 5 of these phenols are masked as methyl ethers in Sal (Figure 1A, 57,58). These 5 methoxyl groups result in more efficient absorption due to increased lipophilicity of Sal (vs polyphenols with six free phenols), as shown by its short half-life (approximately $1 \mathrm{~h}$ ) in plasma (30). To be efficiently eliminated, the methoxyl groups of Sal must be O-demethylated by cytochrome P450dependent oxidation, a slower Phase 1 reaction which also unmasks antioxidant phenolic groups. Once formed, phenols are rapidly conjugated by Phase 2 enzymes and the sulfate or glucuronide conjugates rapidly eliminated by active transporters in the liver (bile) and kidney (urine),

We believe compounds similar to Sal can serve as important components of defined TCM mixtures used for chemoprotection in vivo due to their prolonged antioxidant activity and delayed metabolic clearance. Another approach to achieve the same pharmacokinetic and pharmacodynamic goals is by synthesis of lipophilic derivatives of antioxidant phenolic hydroxyls in TCM ingredients. Thus, five novel alkyl ether (ethyl, butyl, pentyl, hexyl and octyl) derivatives of Res were recently prepared which increased bioavailability compared to Res. Significantly, these derivatives retained the pharmacodynamic (melanogenesis inhibition) effect of Res evaluated (60) so that a mixture of Res and Alkyl-O-Res could be formulated to have both immediate and more prolonged biological activity based on rate of metabolic elimination and unmasking of antioxidant phenolic groups over time. In this respect, the metabolism of the ethyl ether would be more rapid than with any of the other alkyl ethers, with O-deoctylation being the slowest P450catalyzed reaction in this series. 


\section{ACKNOWLEDGEMENTS}

This research was funded by CIHR grant MOP-9972 to JRB and CIHR grant FRN-115135 to RJR; by a Hospital for Sick Children Foundation grant to MJR, JRB and A. Lau; and by an Ontario Ministry of Research and Innovation: International Strategic Opportunities Program grant to MJR, JRB and DC. We are grateful to Ms. Lianne Dale for assistance with the confocal microscopy experiments, to Dr. Ken Yeung, Western Department of Biochemistry Proteomics Centre and Ms. Paula Pittock, London Regional Genomics Centre for assistance with the mass spectrometry experiments.

\section{REFERENCES}

1. Halliwell B. The wanderings of a free radical. Free Radic Biol Med, 2009; 46:531-542.

2. Ljubisavljevic S, Stojanovic I. Neuroinflammation and demyelination from the point of nitrosative stress as a new target for neuroprotection. Rev Neurosci, 2015; 26:49-73.

3. Pisochi AM, Pop A. The role of antioxidants in the chemistry of oxidative stress: A review. Eur J Med Chem, 2015; 97:55-74.

4. Buttke TM, Sandstrom PA. Oxidative stress as a mediator of apoptosis. Immunol. Today, 1994; 15:710.

5. Sahaf B, Heydari K, Herzenberg LA. Lymphocyte surface thiol levels. Proc Natl Acad Sci USA, 2003; 100: 4001-4005.

6. Castellani R, Smith, MA, Richey PL, Perry G. Glycoxidation and oxidative stress in Parkinson disease and diffuse Lewy body disease. Brain Res, 1996; 737: 195-200.

7. Mieyal JJ, Gallogly MM, Qanungo S, Sabens EA, Shelton, MD. Molecular mechanisms and clinical implications of reversible protein Sglutathionylation. Antioxid Redox Signal, 2008, 10: 1941-88.

8. Addayed ME, Abd El-Aty AM. Cruciferous plants: phytochemical toxicity versus cancer chemoprotection. Mini Rev Med Chem, 2009; 9:1470-1478.

9. Virmani A, Pinto L, Binienda Z, Ali S. Food, nutrigenomics, and neurodegeneration-neuroprotection by what you eat, Mol Neurobiol, 2013; 48:353-362.

10. Quan Y, Wang ZY, Xiong M, Xiao ZT, Zhang HY. Dissecting traditional Chinese medicines by omics and bioinformatics. Nat Prod Commun, 2014; 9:1391-1396.

11. Zhang L, Chen DF, Xia XY, Yip C, Rieder MJ, Bend JR. Potential complementary therapy for adverse drug reactions to sulfonamides: chemoprotection against oxidative and nitrosative stress by TCM constituents and defined mixtures. J Pharm Pharm Sci, 2015; 18:xxx-xxx.

12. Dong Q, Banaich MS, O'Brien PJ. Cytoprotection by almond skin extracts or catechins of hepatocyte cytotoxicity induced by hydroperoxide (oxidative stress model) versus glyoxal or methylglyoxal (carbonylation model). Chem Biol Interact, 2010; 185:101-109.

13. Rashid K, Sinha K, Sil PC. An update on oxidative stress-mediated organ pathophysiology. Food Chem Toxicol, 2013; 62:584-600.

14. Dobransky T, Davis WL, Rylett RJ. Functional characterization of phosphorylation of $69-\mathrm{kDa}$ human choline acetyltransferase at serine 440 by protein kinase C. J Biol Chem, 2001; 276:22244-22250.

15. Resendes MC, Dobransky T, Ferguson SS, Rylett RJ. Nuclear localization of the $82-\mathrm{kDa}$ form of human choline acetyltransferase. J Biol Chem, 1999; 274:19417-19421.

16. Tan S, Zhou S, Luo Y. Baicalein pretreatment confers cardioprotection against acute myocardial infarction by activating the endothelial nitric oxide synthase signaling pathway and inhibiting oxidative stress. Mol Med Rep, 2014; 9:2429-2434.

17. Yang L, Qian Q, Ji H, Yang R, Wang L, Xi L, Sheng L, Zhao B, Zhang X. Inhibitory effect on protein kinase Ctheta by Crocetin attenuates palmitateinduced insulin insensitivity in 3T3-L1 adipocytes. Eur J Pharmacol, 2010; 642:47-55.

18. Wang G, Dai F, Yu K, Jia Z, Zhang A, Huang Q, Kang C, Jiang $\mathrm{H}, \mathrm{Pu}$ P. Resveratrol inhibits glioma cell growth via targeting oncogenic microRNAs and multiple signaling pathways. Int J Oncol, 2015; 46:1739-1747.

19. Arumuggam N, Bhowmick NA, Rupasinghe HP. A Review: Phytochemicals Targeting JAK/STAT Signaling and IDO Expression in Cancer. Phytother Res, 2015; 29:805-817.

20. Hwang JM, Tseng TH, Tsai YY, Lee HJ, Chou FP, Wang CJ, Chu CY. Protective effects of baicalein on tert-butyl hydroperoxide-induced hepatic toxicity in rat hepatocytes. J Biomed Sci, 2005; 12:389-397.

21. Habtemariam S. Activity-guided isolation and identification of antioxidant components from ethanolic extract of Peltiphyllum peltatum (Torr). Nat Prod Commun, 2008; 3:1321-1324.

22. Habtemariam S. Activity-guided isolation and identification of free radical-scavenging components from ethanolic extract of boneset (leaves of Eupatorium perfoliatum). Nat Prod Commun, 2008; 3:1317-1320.

23. Fang YH, Li DP, Liu XJ, Sun YR, Cao ZQ. Scavenging effects of baicalin and its copper (II), zinc (II) complexes on superoxide radical. Chin J Biochem Mol Biol, 1991; 6:21-26. 
24. Huang WW, Kuo YH, Chin CC, Wang JY, Yu HR, Sheen JM, Tung SY, Shen CH, Chen TC, Sung ML, Liang HF, Kuo HC. Proteomic analysis of the effects of baicalein on colorectal cancer cells. Proteomics, 2012, 12: 810-819.

25. Giaccio M. Crocetin from saffron: an active component of an ancient spice. Crit Rev Food Sci Nutr, 2004; 44:155-172.

26. Erben-Russ M, Michel C, Bors W, Saran M. Determination of sulfite radical (SO 3.-) reaction rate constants by means of competition kinetics. Radiat Environ Biophys, 1987; 26:289-294.

27. Trela BC, Waterhouse AL. Resveratrol: isomeric molar absorptivities and stability. J Agric Food Chem, 1966; 44:1523-1527.

28. de la Lastra CA, Villegas I. Resveratrol as an antioxidant and pro-oxidant agent: mechanisms and clinical implications. Biochem Soc Trans, 2007; 35:1156-1160.

29. Jia Z, Zhu H, Misra BR, Mahaney JE, Li Y, Misra HP. EPR studies on the superoxide-scavenging capacity of the nutraceutical resveratrol. Mol Cell Biochem, 313:187-194, 2008.

30. Wei H, Xu W, Cai F, Zhao G, Feng J, Sun L, Chen W. Simultaneous determination of five lignan constituents of Wuzhi capsule in rat plasma by LCMS/MS: application to pharmacokinetic study. J Pharm Biomed Anal, 2010; 52: 741-746.

31. Lin TJ, Liu GT, Pan Y, Liu Y, Xu GZ. Protection by schisanhenol against adriamycin toxicity in rat heart mitochondria. Biochem Pharmacol, 1991; 42:18051810.

32. Lin T, Liu G, Pan Y. Protective effect of schisanhenol against oxygen radical induced mitochondrial toxicity on rat heart and liver. Biomed Environ Sci, 1992; 5:57-64.

33. Yu LH, Liu GT, Sun YM, Zhang HY. Antioxidative effect of schisanhenol on human low density lipoprotein and its quantum chemical calculation. Acta Pharmacol Sin, 2004; 25:1038-1044.

34. Lu H, Liu GT. Effect of dibenzo[a,c]cyclooctene lignans isolated from Fructus schizandrae on lipid peroxidation and anti-oxidative enzyme activity. Chem Biol Interact, 1991; 78:77-84.

35. Leichert LI, Jakob U. Global methods to monitor the thiol-disulfide state of proteins in vivo. Antioxidants Redox Signaling, 2006; 8:763-772.

36. Lindahl M, Mata-Cabana A, Kieselbach T. The disulfide proteome and other reactive cysteine proteomes: analysis and functional significance. Antioxid Redox Signal, 2011; 14:2581-2642.

37. Lowry OH, Rosebrough NJ, Farr AL, Randall RJ. Protein measurement with the Folin phenol reagent. J Biol Chem, 1951; 193:265-275.

38. Korzeniewski C, Callewaert DM. An enzyme-release assay for natural cytotoxicity. J Immunol Methods, 1983; 64:313-320.
39. Habig WH, Pabst MJ, Jakoby WB. Glutathione Stransferases. The first enzymatic step in mercapturic acid formation. J. Biol. Chem, 1974; 249:7130-7139.

40. Dooley CT, Dore TM, Hanson GT, Jackson WC, Remington SJ, Tsien RY. Imaging dynamic redox changes in mammalian cells with green fluorescent protein indicators. J Biol Chem, 2004; 279:2228422293.

41. Hanson GT, Aggeler R, Oglesbee D, Cannon M, Capaldi RA, Tsien RY, Remington J. Investigating mitochondrial redox potential with redox-sensitive green fluorescent protein indicators. J Biol Chem, 2004; 279:13044-13053.

42. Cumming RC, Andon NL, Haynes PA, Park M, Fischer WH, Schubert D. Protein disulfide bond formation in the cytoplasm during oxidative stress. $\mathrm{J}$ Biol Chem, 2004; 279:21749-21758.

43. Shevchenko A, Wilm M, Vorm O, Mann M. Mass spectrometric sequencing of proteins silver-stained polyacrylamide gels. Anal Chem, 1996; 68:850-858.

44. Kim AR, Dobransky T, Rylett RJ, Shilton BH. Surface-entropy reduction used in the crystallization of human choline acetyltransferase. Acta Crystallogr D Biol Crystallogr, 2005; 61:1306-1310.

45. Kim AR, Rylett RJ, Shilton BH. Substrate binding and catalytic mechanism of human choline acetyltransferase. Biochemistry, 2006; 45:1462114631.

46. Rhee SG, Cha HZ, Kim K. Peroxiredoxins: A historical overview and speculative preview of novel mechanisms and emerging concepts in cell signaling. Free Radic Biol Med, 2005; 38:1543-1552.

47. Wood ZA, Schroder E, Robin Harris J, Poole LB. Structure, mechanism and regulation of peroxiredoxins. Trends Biochem Sci, 2003; 28:32-40.

48. Woo HA, Kang SW, Kim HK, Yang KS, Chae HZ, Rhee SG. Reversible oxidation of the active site cysteine of peroxiredoxins to cysteine sulfinic acid. Immunoblot detection with antibodies specific for the hyperoxidized cysteine-containing sequence. J Biol Chem, 2003; 278:47361-47364.

49. Cho CS, Lee S, Lee GT, Woo HA, Choi EJ, Rhee SG. Irreversible inactivation of glutathione peroxidase 1 and reversible inactivation of peroxiredoxin II by $\mathrm{H}_{2} \mathrm{O}_{2}$ in red blood cells. Antioxid Redox Signal, 2010; 12:1235-1246.

50. Lv W, Piao JH, Jiang JG. Typical toxic components in traditional Chinese medicine. Expert Opin Drug Saf, 2012; 11:985-1002.

51. Prasad KD, Ram MS, Sawhney RC, Ilavazhagan G, Banerjee PK. Mechanism of tert-butylhydroperoxide induced cytotoxicity in U-937 macrophages by alteration of mitochondrial function and generation of ROS. Toxicol In Vitro, 2007; 21:846-854.

52. Altman SA, Zastawny TH, Rander L, Lin Z, Lumpkin JA, Remacle J, Dizdaroglu M, Rao G. tert-Butyl 
hydroperoxide mediated DNA base damage in cultured mammalian cells. Mut Res, 1994; 306:35-44.

53. Sestili P, Guidarelli A, Dacha M, Cantoni O. Quercetin prevents DNA single strand breakage and cytotoxicity caused by tert-butyl hydroperoxide: Free radical scavenging versus iron chelating mechanism. Free Radic Biol Med, 1998; 25:196-200.

54. Mirabellib F, Salisb A, Marinonib V, Finardib G, Bellomob G, Thor H, Orrenius S. Menadione-induced bleb formation in hepatocytes is associated with the oxidation of thiol groups in actin. Arch Biochem Biophys, 1988; 264:261-269.

55. Dalle-Donne I, Rossi R, Giustarini D, Colombo R, Milzani A. Actin S-glutathionylation: evidence against a thiol-disulphide exchange mechanism Free Radic Biol Med, 2003; 35:1185-1193.
56. Johansson M, Lundberg M. Glutathionylation of beta-actin via a cysteinyl sulfenic acid intermediary, BMC Biochem, 2007; 8:26.

57. Aquilano K, Baldelli S, Ciriolo MR. Glutathione: new roles in redox signaling for an old antioxidant. Front Pharmacol, 2014; 5:196. doi: 10.3389/fphar.2014.00196. eCollection.

58. M. Chen M, N. Kilgore N, H.K. Lee HK, Chen DF. Rubrisandrins $\mathrm{A}$ and $\mathrm{B}$, lignans and related anti-HIV compounds from Schisandra rubriflora. J Nat Prod, 2006; 69: 1697-1701.

59. Lu Y, Chen DF. Analysis of Schisandra chinensis and Schisandra sphenanthera. J Chromatogr A, 2009; 1216:1980-1990.

60. Liu Q, Kim C, Jo YH, Kim SB, Hwang BY, Lee MK. Synthesis and biological evaluation of resveratrol derivatives as melanogenesis inhibitors. Molecules, 2015; 20:16933-16945. 